\title{
多層地盤における杭基礎の水平力作用時の応力二変形系 SYSTEMATIC ELASTIC THEORY ON STRESS AND DEFORMATION OF PILE FOUNDATION. WITH SUPERSTRUCTURE ON MULTIPLE LAYER GROUND SUBJECTED TO LATERAL LOAD
}

中 澤瑤子*

Yohko NAKAZAWA

\begin{abstract}
The aim of this paper is to systematically identify the characteristics regarding the stress/deformation of pile foundations with super-structure subjected to lateral load on multiple layers ground by elastic analysis. The characteristics of stress/deformation of piles could be treated as equivalent to single layer ground. The values of equivalent ground factor $\beta$ 。 for pile top bending moment $\mathrm{M}_{\mathrm{o}}, \beta_{\mathrm{m}}$ for maximum bending moment along pile length $\mathrm{M}_{\mathrm{m}}$ and $\beta_{\mathrm{a}}$ for pile top shear force $\mathrm{Q}_{0}$ were strongly related to the non-dimensional depth of the upper layer. The influence of structural rigidity and the difference between center and corner piles were able to be evaluated by non-dimensional restraint factor $\omega$.
\end{abstract}

Keywords: pile foundation, elastic analysis, double layer ground, superstructure, lateral load, equivalent ground factor, non-dimensional restraint factor

杭基礎、弾性解析、2 層地盤、上部架構、水平力、等価地盤定数、無次元回転拘束度

1.はじめに

上部架構からの水平反力を受けた杭の応力、変形を考える場合、 上部架構と基礎はそれぞれ別の構造系に属するとして切り離して扱 われることが多い。その場合、杭頭の境界を杭頭結合度いわゆる杭 頭固定度 ${ }^{1)}$ で把握し、架構では支点からの曲げ戻しのモーメントを考 慮する考え方乵ある。しかし、この固定度と称するものは、基礎は 剛で回転しないものとして、それへの杭頭の埋込み状況の堅固さを 示す量であって、基礎が架構と一体であれば杭頭も基礎と共に回転 しながら水平に移動するという境界条件を再現するものではない。 この証左として、杭と架構を連続させて応力、変形を求めると、固 定度が架構内の全ての杭で同一であうても、隅基礎と中基礎の杭で はその态力、変形が異なる 礎の特性のうち、地盤が杭全長にわたって一定の場合(これを、1層 地盤と称寸る)にういては、杭への地盤反力を弾性バネ定数として扱 った上で、架構と杭を一体とした解析に基づいた一つの応力/変形 系を文献》に示した。なお、これは、隅、中基䃈の応力、変形はそれ ぞれ絶対量では異なるものの、両基礎の応力／変形には共通する定 性的かつ定量的特性が見出せたため、杭種や架構を限定しないひと つの応力/変形系として示したものである。ここに、隅・中基礎を 総称する場合は、これを杭基礎と呼ぶこととする。
しかし、地盤が多層の場合や一部範囲が液状化して水平抵抗が低 诚し2層とみなせる場合など、多層地盤における杭帛あるいは杭基礎 の挙動はまだ系統的に明らかになっているとは言い難い。コンピュ 一タの普及によってこれらの解析は容易になってきたものの、結果 の工学的位置付けや正否の判断が困難となってゆくであろうことは、 この他の杭の解析分野における状況などからも推察できる。また、 最近の大地震の影響もあって、地盤からの外力によって杭の応力・ 変形を説明しようとする動向が多く見られる6゙な゙が、この場合であ っても上部架構が大きい場合はその慣性力による忘力・変形は無視 することはできずわ、杭の挙動の基本をなすものであることは否めな い。このような視点にたって、本報は、多層地盤、特に2層地盤につ

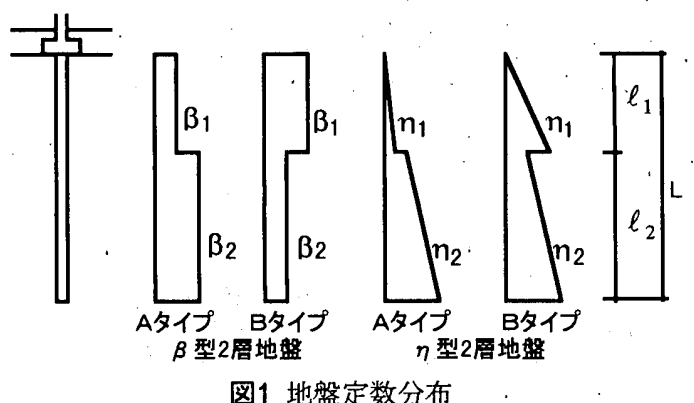


いて、杭頭に水平力を受けた場合の杭基礢の挙動を、杭と架構を一体 とした解析によって系統的に明らかにするものである。图1に2層地盤 における地盤定数分布を模式的に示した。地盤を $\mathrm{k}_{\mathrm{h}}$ の一定值で表す場 合を $\beta$ 型 $\left(\beta=\left(\mathrm{k}_{\mathrm{h}} \mathrm{D} /\left(4 \mathrm{E}_{\mathrm{p}} \mathrm{I}_{\mathrm{p}}\right)\right)^{0.25} 、 \mathrm{D}\right.$ : 杭径、 $\mathrm{E}_{\mathrm{p}} \mathrm{I}_{\mathrm{p}}$ : 杭の曲げ㓮性)、 $\mathrm{k}_{\mathrm{h}}$ が 深さ $x$ に比例する場合 $\left(\mathrm{k}_{\mathrm{h}}=\mathrm{n}_{\mathrm{h}} \cdot \mathrm{x} / \mathrm{D}\right)$ を $\eta$ 型 $\left(\eta=\left(\mathrm{n}_{\mathrm{h}} /\left(\mathrm{E}_{\mathrm{p}} \mathrm{I}_{\mathrm{p}}\right)^{0.2}\right)\right.$ と呼ぶ。上・ 下層はサフィックス1、2で区別する。上層の地盤定数が下層よりも 小さい場合 $\left(\beta_{1}<\beta_{2}\right.$ および $\left.\eta_{1}<\eta_{2}\right)$ をAタイプ、大きい場合 $\left(\beta_{1}>\beta_{2}\right.$ お よび $\left.\eta_{1}>\eta_{2}\right)$ をタタプと呼ぶ。

\section{2. 架構と杭基㸴の一体解析法の概要}

架構モデルは1層3スパンの骨組架構であって、杭基礎は1柱1杭形 式である。解析に用いる杭種はPC杭および場所打ちコンクリート杭 としたが、本報の結果は杭種および架構を限定しない一般的な特性 である。解析では、杭および架構部材は弾性線材として扱うことと する。解析はまず、杭の区分解析を行う。方法は、杭を長さ方向に 適宜区分し、区分ごとに杭の弾性支承梁理論(1)式を適用、区分の境 界条件を一致させて杭全長を解くものである。なお、(1)式を各区分 に適用するにあたって、 $\mathrm{k}_{\mathrm{h}}$ は区分間の平均值を採用した。結果とし て、杭頭の応力変形式が(2) (5)式の形で得られる。ここに、Qo： 杭頭水平力、 $\mathrm{Mo}$ : 杭頭曲げモーメント、yo : 杭頭水平変位、 $\theta 0$ : 杭頭回転角である。Koz'、Koy'、Kom'は区分解析で得られる俰数値 である。

杭の基本式 : $\mathrm{E}_{\mathrm{p}} \mathrm{I}_{\mathrm{p}} \mathrm{d}^{4} \mathrm{y} / \mathrm{dx} \mathrm{x}^{4}+\mathrm{k}_{\mathrm{h}} \times \mathrm{D} \times \mathrm{y}=0$

$\beta$ 型: $\mathrm{Qo}=4 \mathrm{Koz}^{3} \times \mathrm{yo} \times \mathrm{E}_{\mathrm{p}} \mathrm{I}_{\mathrm{p}} \beta_{1}{ }^{3}-2 \mathrm{Koy}^{\prime} \times \theta 0 \times \mathrm{E}_{\mathrm{p}} \mathrm{I}_{\mathrm{p}} \beta_{1}{ }^{2}$

$\mathrm{Mo}=-2 \mathrm{Koy}^{\prime} \times$ yo $\times \mathrm{E}_{\mathrm{p}} \mathrm{I}_{\mathrm{p}} \beta_{1}{ }^{2}+2 \mathrm{Kom}^{\prime} \times \theta \mathrm{o} \times \mathrm{E}_{\mathrm{p}} \mathrm{I}_{\mathrm{p}} \beta_{1}$

$\eta$ 型 : $\mathrm{Qo}=4 \mathrm{Koz}^{3} \times$ yo $\times \mathrm{E}_{\mathrm{p}} \mathrm{I}_{\mathrm{p}} \eta_{1}{ }^{3}-2 \mathrm{Koy} \times \theta 0 \times \mathrm{E}_{\mathrm{p}} \mathrm{I}_{\mathrm{p}} \eta_{1}{ }^{2}$

$\mathrm{Mo}=-2 \mathrm{Koy}^{\prime} \times$ yo $\times \mathrm{E}_{\mathrm{p}} \mathrm{I}_{\mathrm{p}} \eta_{1}{ }^{2}+2 \mathrm{Kom}^{\prime} \times \theta \mathrm{o} \times \mathrm{E}_{\mathrm{p}} \mathrm{I}_{\mathrm{p}} \eta_{1}$

次いで、杭と架構の一体解析を行う。一体解析法は1層地盤の場合 と同一であって、(2)、(3)式または(4)、(5)式を基礎節点で架構のた わみ角法年の式に連結して節点方程式をたて、その他の架構の方程式 とで連立に解き、架構および杭の応力、変形を得るものである。

本報では、杭頭は基礎に完全に埋め込まれており、基礎が回転す れば杭頭も等しい回転を生ずると仮定した。ただし、杭頭拘束度に ついての一連の特性を得るため、杭頭ピンおよび杭頭が回転しない (基礎固定と略称) 条件でも解析を行った。杭先端はピンと仮定する。 また、基礎の沈下は考慮しないこととした。

解析範囲は、架構の部材剛度は基礎梁剛度 $\mathrm{Kg}=0.005,0.01,0.03 \mathrm{~m}^{3}$ とし、1階柱風度 $\mathrm{K}_{\mathrm{c}}=0.007 \mathrm{~m}^{3} 、 2$ 階梁剛度 $\mathrm{K}_{\mathrm{b}}=0.004 \mathrm{~m}^{3}$ の一定值とする。 部材のヤング係数は $\mathrm{E}_{\mathrm{c}}=210 \times 10^{5} \mathrm{kN} / \mathrm{m}^{2}$ である。杭径は、場所打ちコ ンクリート杭はD $=1.0,1.2,1.4 \mathrm{~m}$ (ヤング係数 : $\mathrm{E}_{\mathrm{p}}=210 \times 10^{5} \mathrm{kN} / \mathrm{m}^{2}$ )、

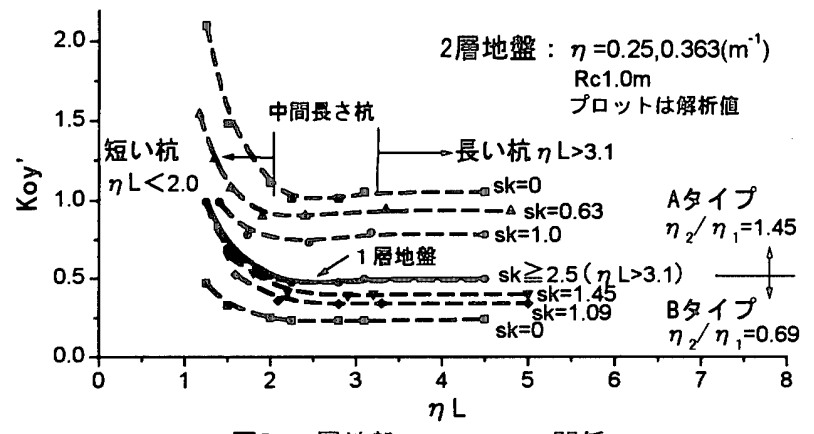

図2 2層地盤のKoy' $-\eta \mathrm{L}$ 関倸
$\mathrm{PC}$ 杭はD $=0.6,0.8 \mathrm{~m}\left(\mathrm{E}_{\mathrm{p}}=400 \times 10^{5} \mathrm{kN} / \mathrm{m}^{2}\right)$ を採用し、杭長さLは $620 \mathrm{~m}$ の任意長さとして、杭径に対して短かすぎるものは省いた。地盤定 数 $\mathrm{k}_{\mathrm{h}}=5,000,10,000,20,000 \mathrm{kN} / \mathrm{m}^{3} 、 \mathrm{n}_{\mathrm{h}}=1,000,2,200,6,500 \mathrm{kN} / \mathrm{m}^{3}$ である。 これは、 $\beta \doteqdot 0.13 \sim 0.4 \mathrm{~m}^{-1} 、 \eta \doteqdot 0.2 \sim 0.5 \mathrm{~m}^{-1}$ 、上下の地盤定数比は $\beta_{2}$ ' $\beta_{1}\left(\eta_{2} / \eta_{1}\right)=0.6 \sim 1.45$ にあたる。以上の範囲で適宜組み合わせて約 200 例の解析を行った。

杭の区分解析によって得られる係数值のうち、 7 型のKoy'- $\eta \mathrm{L}$ 関 係を図2に示した。同図は、2層地盤の杭無次元長さを $\eta \mathrm{L}=\eta_{1} \ell_{1}+\eta_{2}$ $\ell_{2}\left(\ell_{1}:\right.$ 上層厚さ、 $\ell_{2}$ : 下層範囲にある杭の長さ)で表してある。 上層の無次元層厚 $\left(\beta_{1} \ell_{1} 、 \eta_{1} \ell_{1}\right)$ をk で記号化する。 sk一定の場合 のKoy' $-\eta \mathrm{L}$ 関係は1層地盤のKoy $-\eta \mathrm{L}$ 関係4)に比例的な曲線である。 Koz'、Kom'や $\beta$ 型の図は省略したが同様である。このことから、ま ず2層地盤での杭の無次元長さ注、 $\eta \mathrm{L}=\eta_{1} \ell_{1}+\eta_{2} \ell_{2}$ (あるいは $\beta \mathrm{L}=$ $\left.\beta_{1} \ell_{1}+\beta_{2} \ell_{2}\right)$ で表して差し支えないことがわかる。なお、上述の解 析範囲を $\beta \mathrm{L} 、 \eta \mathrm{L}$ で表すと、 $\beta \mathrm{L}=1.3 \sim 5.0 、 \eta \mathrm{L}=1.5 \sim 7.2$ である。図2 からさらに、2層地盤における杭長さの区分も、1層地盤での杭長 さの区分と同一とみてよいことがわかる。すなわち、 $\beta \mathrm{L}>2.5 、 \eta \mathrm{L}$ $>3.1$ は長い杭、 $\beta \mathrm{L}<1.6 、 \eta \mathrm{L}<2.0$ は短い杭にあたる。なお、これ

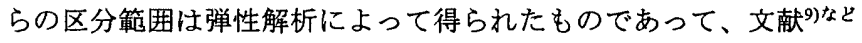
で定義されている区分範囲とは限界值が異なる点に注意されたい。 以後、解析結果をこの杭長さの区分に従って整理する。

\section{3. 長い杭基磽の応力・変形特性}

3.1 曲げモーメントについて

杭基礎の応力、変形はそのままでは一定の共通特性を示さないの で、一体解析の結果得られたMo、地中部最大曲げモーメント $\mathrm{M}_{\mathrm{m}}$ 、 およびQoを杭頭水平変位あたりの値 $\mathrm{Mo} /\left(\mathrm{yoE}_{\mathrm{p}} \mathrm{I}_{\mathrm{p}}\right) 、 \mathrm{M}_{\mathrm{m}} /\left(\mathrm{yoE}_{\mathrm{p}} \mathrm{I}_{\mathrm{p}}\right)$ および $\mathrm{Q} /\left(\mathrm{yoE} \mathrm{E}_{\mathrm{p}} \mathrm{I}_{\mathrm{p}}\right)$ に直して検討を行う。まず、 $\beta$ 型地盤で、層数が2層以上の 多層地盤について、基蓬固定の場合の $\mathrm{Mo} /\left(\mathrm{yoE}_{\mathrm{p}} \mathrm{I}_{\mathrm{p}}\right)-\mathrm{M}_{\mathrm{m}} /\left(\mathrm{yoE}_{\mathrm{p}} \mathrm{I}_{\mathrm{p}}\right)$ 関係 を図3に示した。同図の各点の数字は層数である。地盤は、杭頭か ら無次元長さ2.0の範囲が2 7層の互層で、最上層とその下の第2層 の組み合わせがAタイプでsk=0.94一定の場合、およびBタイプでsk= 0.79一定の場合である。第3層以深の各層の地盤定数は交互に $\beta_{1} 、 \beta_{2}$ に等しいと考えておく。1層地盤の $\mathrm{Mo} /\left(\mathrm{yoE}_{\mathrm{p}} \mathrm{I}_{\mathrm{p}}\right)-\mathrm{M}_{\mathrm{m}} /\left(\mathrm{yoE}_{\mathrm{p}} \mathrm{I}_{\mathrm{p}}\right)$ 関㐿住直 線であり、2層地盤はほほ棈円形の線上にある。その他の多首地盤は この楕中内にあり、かつ層数が増えるにつれて2層地盤の值間で増减 を繰り返しながら1層地盤に近づいてゆくことから、2層の場合が層 序による影響を最も端的に示すと考えられる。以降は2層地盤につい て検討を行う。

$\beta$ 型のA、Bタイプの $\mathrm{Mo} /\left(\mathrm{yoE}_{\mathrm{p}} \mathrm{I}_{\mathrm{p}}\right)-\mathrm{M}_{\mathrm{m}} /\left(\mathrm{yoE}_{\mathrm{p}} \mathrm{I}_{\mathrm{p}}\right)$ 関係を図4、図5に示

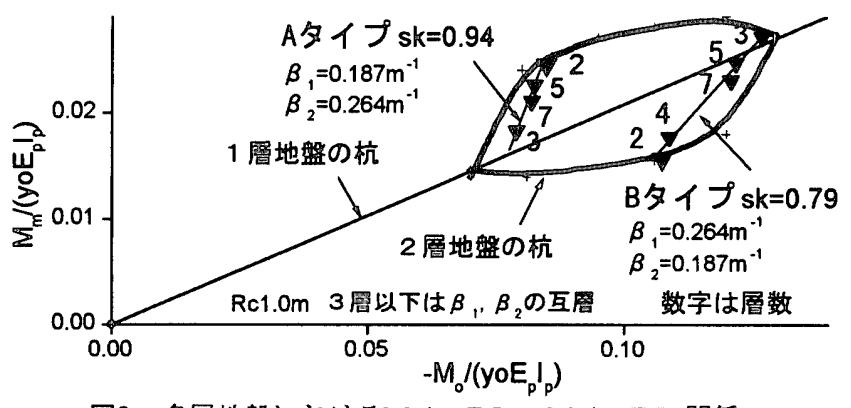

図3多層地盤における $\mathrm{Mo} /\left(\mathrm{yoE}_{\mathrm{p}} \mathrm{I}_{\mathrm{p}}\right)-\mathrm{M}_{\mathrm{m}} /\left(\mathrm{yoE}_{\mathrm{p}} \mathrm{I}_{\mathrm{p}}\right)$ 関倸 
した。 $\mathrm{Kg}$ が一定の場合の $\mathrm{Mo} /\left(\mathrm{yoE}_{\mathrm{p}} \mathrm{I}_{\mathrm{p}}\right)-\mathrm{M}_{\mathrm{m}} /\left(\mathrm{yoE}_{\mathrm{p}} \mathrm{I}_{\mathrm{p}}\right)$ 関係は、隅基礎と 中基礎では異なる曲線であり、Aタイプではskが増大すると诚少し、

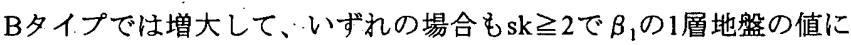
一致する。 $\eta$ 型は図を省略したが、 $\mathrm{sk} \geqq 2.5 て ゙ \eta_{1}$ の1層地盤の值に一 致する。なお、図2のKoy'- $\eta \mathrm{L}$ 曲線も上述のskの範囲で1層地盤の曲 線と重なっている。したがって、2層性を考慮すべき範囲は $\beta$ 型では $0<\mathrm{sk}<2 、 \eta$ 型では $0<\mathrm{sk}<2.5$ の範囲であって、これ以外は杭全長に わたって上層が広がった1層地盤に等しいとみてよい。

図4、図5の各曲線毎に $\omega$ 值を記したが、これらの值は1層地盤の

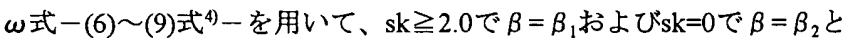
して求めた值である。隅・中基礎の $\mathrm{Mo} /\left(\mathrm{yoE}_{\mathrm{p}} \mathrm{I}_{\mathrm{p}}\right)-\mathrm{M}_{\mathrm{m}} /\left(\mathrm{yoE}_{\mathrm{p}} \mathrm{I}_{\mathrm{p}}\right)$ 曲線は $\omega$ が大きい順に基礎固定 $(\omega=\infty)$ から杭頭ピン $(\omega=0)$ の側へと並んで おり、2層地盤での架構の影響は隅・中基礎の相違も含めて $\omega$ で表現 できると考えられる。ちなみに $\omega=0.5$ は、基礎梁断面が $0.4 \mathrm{~m} \times 1.2 \mathrm{~m}$ 程度、スパン5〜6mの隅基礎で、杭径 $1 \mathrm{~m}$ の 1 柱 1 杭の場所打ちコンク リート杭、あるいは $\mathrm{E}_{\mathrm{p}} \mathrm{I}_{\mathrm{p}}$ を杭数倍にして $\omega$ の概念を 1 基礎複数杭に拡 張適用すれば杭径 $0.6 \mathrm{~m}$ の3本打PC杭基礎に相当する。

$$
\begin{aligned}
& \beta \text { 型：隅基礎 } \omega=\mathrm{EcKg} /\left(\mathrm{E}_{\mathrm{p}} \mathrm{I}_{\mathrm{p}} \beta\right) \\
& \text { 中基礎 } \omega=1.6 \Sigma \mathrm{EcKg} /\left(\mathrm{E}_{\mathrm{p}} \mathrm{I}_{\mathrm{p}} \beta\right) \\
& \eta \text { 型：隅基礎 } \omega=\mathrm{EcKg} /\left(\mathrm{E}_{\mathrm{p}} \mathrm{I}_{\mathrm{p}} \eta\right) \\
& \text {.中基礎 } \omega=1.6 \Sigma \mathrm{EcKg} /\left(\mathrm{E}_{\mathrm{p}} \mathrm{I}_{\mathrm{p}} \eta\right) \\
& \text { ここに、 } \mathrm{EcKg} \text { : 隅基礎の基礎梁曲げ剛度 } \\
& \Sigma \mathrm{EcKg} \text { : 中基礎の左右の基礎梁曲げ剛度の和 }
\end{aligned}
$$

さらに同図から、2層地盤において上層の厚さや基礎梁剛度が変化 する場合の杭基礎の $\mathrm{Mo} /\left(\mathrm{yoE}_{\mathrm{p}} \mathrm{I}_{\mathrm{p}}\right)-\mathrm{M}_{\mathrm{n}} /\left(\mathrm{yoE}_{\mathrm{p}} \mathrm{I}_{\mathrm{p}}\right)$ 関係は不規則な四辺形 の領域を形成することがわかる。この上下限は、上層あるいは下首 地盤が杭全長に広がる1層地盤での值である。1層地盤の杭基礎の応 カ/変形式を(10)〜(15)式に記す。ただし、これらの式は文献)ではKoz、 $\theta$ および $\left(\mathrm{M}_{\mathrm{m}}=\mathrm{c} \times \mathrm{Qo} / \beta\right.$ 等の係数 $)$ 等の記号で表し、杭長さを限定し ない形の式で示したが、ここでは、表1のKoz等の值や文献4)の $\theta-$ $\omega$ 関係図(ここに、 $\theta=\theta \mathrm{o} /(\mathrm{yo} \beta)$ あるいは $\theta \mathrm{o} /(\mathrm{yo} \eta))$ における 関係 $(\beta$ 型で $\omega>0.5: \theta=1 /(2 \omega+1) 、 \mathrm{c}=0.104+1 /(18 \omega+15) 、 \eta$ 型で $\omega$ $>0.8: \theta=1 /(4.5 \omega+1.6) 、 \mathrm{c}=0.26+1 /(19 \omega+6))$ を考虑して、 $\omega$ の関倸 式として示した。

表1 Koz、Koy、Kom

\begin{tabular}{|l|l|l|l||l|l|l|l|}
\hline$\beta \mathrm{L}$ & Koz & Koy & Kom & $\eta \mathrm{L}$ & Koz & Koy & Kom \\
\hline$\geqq 2.5$ & 1.0 & 1.0 & 1.0 & $\geqq 3.1$ & 0.27 & 0.5 & 0.75 \\
\hdashline 1.8 & 0.95 & 0.95 & 1.02 & 2.0 & 0.24 & 0.54 & 0.83 \\
\hline 1.5 & 0.94 & 1.05 & 1.15 & 1.5 & 0.32 & 0.7 & 1.0 \\
\hline
\end{tabular}

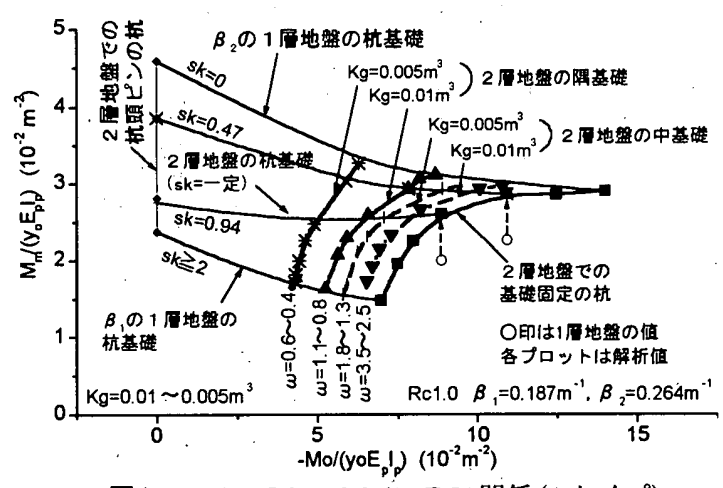

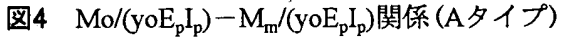

杭基礎 : $\mathrm{Mo} /\left(\mathrm{yoE}_{\mathrm{p}} \mathrm{I}_{\mathrm{p}}\right)=(-2+2 /(2 \omega+1)) \times \beta^{2} \quad$ かつ $\mathrm{M}_{\mathrm{m}} /\left(\mathrm{yoE}_{\mathrm{p}} \mathrm{I}_{\mathrm{p}}\right)=(0.104+1 /(18 \omega+15)) \times(4-2 /(2 \omega+1)) \times \beta^{2}$ $\mathrm{Mo} /\left(\mathrm{yoE}_{\mathrm{p}} \mathrm{I}_{\mathrm{p}}\right)=(-1+1.5 /(4.5 \omega+1.6)) \times \eta^{2} \quad$ かつ

$\mathrm{M}_{\mathrm{m}} /\left(\mathrm{yoE}_{\mathrm{p}} \mathrm{I}_{\mathrm{p}}\right)=(0.26+1 /(19 \omega+6)) \times(1.08-1 /(4.5 \omega+1.6)) \times \eta^{2}(11)$

基礎固定 : $\mathrm{Mo} /\left(\mathrm{yoE}_{\mathrm{p}} \mathrm{I}_{\mathrm{p}}\right)=-2 \beta^{2}$ かつ $\mathrm{M}_{\mathrm{m}} /\left(\mathrm{yoE}_{\mathrm{p}} \mathrm{I}_{\mathrm{p}}\right)=0.416 \beta^{2}$ $\mathrm{Mo} /\left(\mathrm{yoE}_{\mathrm{p}} \mathrm{I}_{\mathrm{p}}\right)=-\eta^{2}$ かつ $\mathrm{M}_{\mathrm{m}} /\left(\mathrm{yo} \mathrm{E}_{\mathrm{p}} \mathrm{I}_{\mathrm{p}}\right)=0.28 \eta^{2}$

杭頭ピン: $\mathrm{M}_{\mathrm{m}} /\left(\mathrm{yoE}_{\mathrm{p}} \mathrm{I}_{\mathrm{p}}\right)=0.644 \beta^{2}$

$\mathrm{M}_{\mathrm{m}} /\left(\mathrm{yoE}_{\mathrm{p}} \mathrm{I}_{\mathrm{p}}\right)=0.322 \eta^{2}$

ここに、、 $\beta=\beta_{1}$ および $\beta_{2}$ あるいは $\eta=\eta_{1}$ および $\eta_{2}$

一方、 $\mathrm{Mo} /\left(\mathrm{yoE}_{\mathrm{p}} \mathrm{I}_{\mathrm{p}}\right)-\mathrm{M}_{\mathrm{m}} /\left(\mathrm{yoE}_{\mathrm{p}} \mathrm{I}_{\mathrm{p}}\right)$ の領域の左右の限界汭層地盤にお ける杭頭ピンおよび基礎固定の值である。これらは、(3)あるいは(5) 式においてMo=0あるいは $\theta \mathrm{o}=0$ とした式で得た。同式のKoy'等の係 数値は上下の地盤定数、その比およびskが関係する值であり、一般 特性注明らかでないため、解析で得た応力值の一般特性をこれらの 式によって考察することとは容易でない。しかし、図2における2層地 盤のKoy'值と1層地般のKoyの間にはskを介した比例的関係が見られ るため、2層地盤注等価な1層地盤に置換できると考えた。

2層地盤を等価な1層地盤に置換した式(等価式と略称)は、1層地盤 と同じ形式とし、Moおよび $\mathrm{M}_{\mathrm{m}}$ の等価式を(16)〜(19)式に示した。等 価地盤定数は、Moに関しては $\beta_{0} 、 \eta_{\mathrm{o}}$ で、また $\mathrm{M}_{\mathrm{m}}$ に関しては $\beta_{\mathrm{m}} 、 \eta_{\mathrm{m}}$ で記号化した。基礎固定の場合の $\beta_{0} 、 \eta_{0}$ は、2層地盤で基礎固定の解 析で得た Mo/yo值を1層地盤の式に代入して $\beta_{\mathrm{o}}=\left(\mathrm{Mo} /\left(2 \mathrm{yoE}_{\mathrm{p}} \mathrm{I}_{\mathrm{p}}\right)\right)^{1 / 2} 、 \eta_{\mathrm{o}}=$ $\left(\mathrm{Mo} /\left(\mathrm{yoE} \mathrm{E}_{\mathrm{p}} \mathrm{I}_{\mathrm{p}}\right)\right)^{1 / 2}$ で得た。これを、 $\left(\beta_{1}-\beta_{\mathrm{o}}\right) /\left(\beta_{1}-\beta_{2}\right) 、\left(\eta_{1}-\eta_{\mathrm{o}}\right) /\left(\eta_{1}-\eta_{2}\right)$ で 無次元化(これを $\Delta_{\mathrm{o}}$ で記号化)し、 $\Delta_{\mathrm{o}}$ - $\mathrm{sk}$ 関係を図6、図7に示した。 $\Delta_{\mathrm{o}}$ は地盤、杭条件に関わらずskでほぼ一義的に決まる值であったの で、 $\beta_{0} 、 \eta_{\mathrm{o}}$ は(20)、(21)式で表せた。 $\Delta_{\mathrm{o}}$ 值を表2に示す。 $\beta_{\mathrm{m}} 、 \eta_{\mathrm{m}}$ は、 2層地盤での解析で得た $\mathrm{M}_{\mathrm{m}} / \mathrm{yo}$ 值を 1 層地盤の式に代入し、基䃈固定の 場合は $\beta_{\mathrm{m}}=\left(\mathrm{M}_{\mathrm{mm}} /\left(0.416 \mathrm{yoE}_{\mathrm{p}} \mathrm{I}_{\mathrm{p}}\right)\right)^{1 / 2} 、 \eta_{\mathrm{m}}=\left(\mathrm{M}_{\mathrm{m}} /\left(0.28 \mathrm{yoE}_{\mathrm{p}} \mathrm{I}_{\mathrm{p}}\right)\right)^{1 / 2}$ 、杭頭ピンの場 合は $\beta_{\mathrm{m}}=\left(\mathrm{M}_{\mathrm{m}} /\left(0.644 \mathrm{yoE}_{\mathrm{p}} \mathrm{I}_{\mathrm{p}}\right)\right)^{1 / 2} 、 \eta_{\mathrm{m}}=\left(\mathrm{M}_{\mathrm{m}} /\left(0.322 \mathrm{yoE}_{\mathrm{p}} \mathrm{I}_{\mathrm{p}}\right)\right)^{1 / 2}$ で得た。これ らを、 $\left(\beta_{1}-\beta_{\mathrm{m}}\right) /\left(\beta_{1}-\beta_{2}\right) 、\left(\eta_{1}-\eta_{\mathrm{m}}\right) /\left(\eta_{1}-\eta_{2}\right)$ で無次元化 ( $\Delta_{\mathrm{m}}$ で記号化)す ると、図8、図9となり、 $\Delta_{\mathrm{m}}$ もskでほぼ一義的に決まる值であったの

表2 $\Delta_{\mathrm{o}}$
\begin{tabular}{|l|l:c|}
\hline sk & $\beta$ 型 & $\eta$ 型 \\
\hline 0 & 1.0 & 1.0 \\
\hline 0.5 & 0.64 & 0.88 \\
\hdashline 1.0 & 0.33 & 0.58 \\
\hdashline 1.5 & 0.12 & 0.3 \\
\hdashline 2.0 & 0 & 0.08 \\
\hline 2.5 & 0 & 0 \\
\hline
\end{tabular}

表3 $\Delta_{\mathrm{m}}$
\begin{tabular}{|l|c|c|c|c|}
\hline \multirow{2}{*}{$\mathrm{sk}$} & \multicolumn{2}{|c|}{ 基礎固定 } & \multicolumn{2}{|c|}{ 杭頭ピン } \\
\cline { 2 - 5 } & $\beta$ 型 & $\eta$ 型 & $\beta$ 型 & $\eta$ 型 \\
\hline 0 & 1.0 & 1.0 & 1.0 & 1.0 \\
\hdashline 0.5 & 1.0 & 1.0 & 0.66 & 0.9 \\
\hdashline 1.0 & 0.72 & 0.86 & 0.2 & 0.66 \\
\hdashline 1.5 & 0.3 & 0.66 & 0.05 & 0.27 \\
\hdashline 2.0 & 0 & 0.36 & 0 & 0.06 \\
\hdashline 2.5 & 0 & 0.15 & 0 & 0 \\
\hline
\end{tabular}

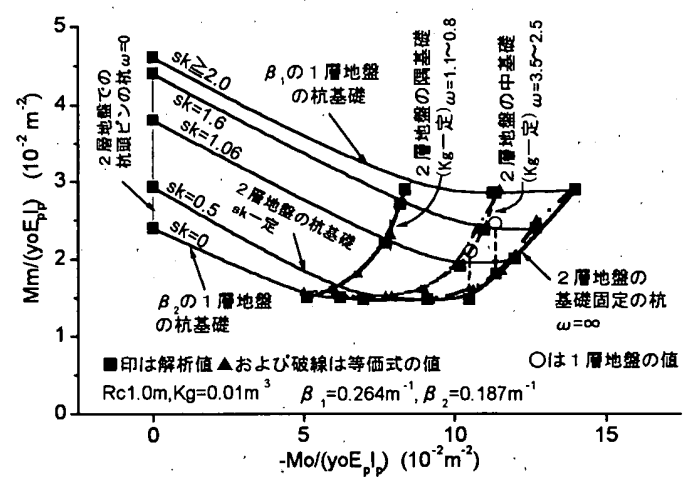

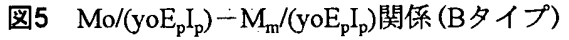


で、 $\beta_{\mathrm{m}} 、 \eta_{\mathrm{m}}$ は(22)、(23)式で表せた。 $\Delta_{\mathrm{m}}$ 值を案3に示す。以後、等価 式の表記は1層地盤の式と区別するため、下線を付した。

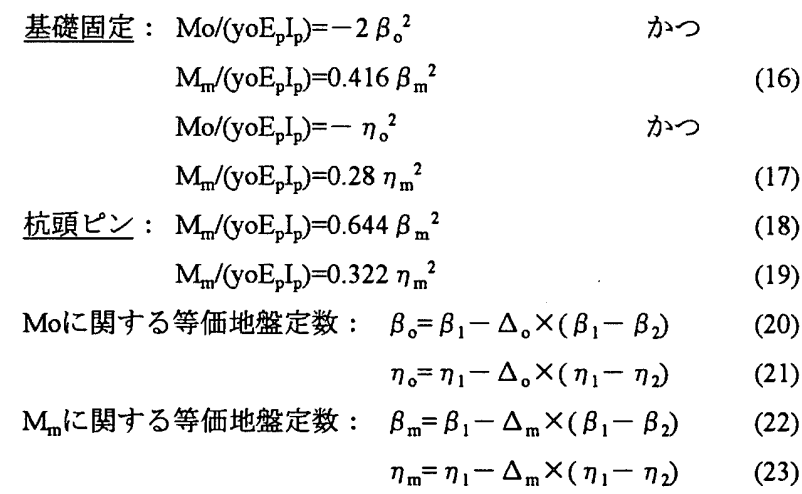

図4、図5に、 $\mathrm{Mo} /\left(\mathrm{yoE}_{\mathrm{p}} \mathrm{I}_{\mathrm{p}}\right)$ 一定に対する1層地盤での $\mathrm{M}_{\mathrm{m}} /\left(\mathrm{yoE}_{\mathrm{p}} \mathrm{I}_{\mathrm{p}}\right)$ を白 丸で例示し、これに対応する2首地盤の $\mathrm{M}_{\mathrm{m}} /\left(\mathrm{yoE}_{\mathrm{p}} \mathrm{I}_{\mathrm{p}}\right)$ 一破線矢印を引い ておいた。破線矢印の長さは1層と2層の $\mathrm{M}_{\mathrm{m}} /\left(\mathrm{yoE}_{\mathrm{p}} \mathrm{I}_{\mathrm{p}}\right)$ の差を表してお り、2層地盤の $\mathrm{M}_{\mathrm{m}}\left(\mathrm{yoE}_{\mathrm{p}} \mathrm{I}_{\mathrm{p}}\right)$ は1層地盤と比べて、 $\mathrm{Mo} /\left(\mathrm{yoE}_{\mathrm{p}} \mathrm{I}_{\mathrm{p}}\right)$ の定值に 対してAタイプでは大きく、Bタイプでは小さいという特徴が見られ る。この特性は、図6〜図9においてsk一定では $\Delta_{\mathrm{m}}>\Delta_{\mathrm{o}}$ であって、(20) （23)式によって等価地盤定数が、Aタイプは $\beta_{\mathrm{m}}>\beta_{0} 、 \eta_{\mathrm{m}}>\eta_{0} 、$ ま たBタイプは $\beta_{\mathrm{m}}<\beta_{0} 、 \eta_{\mathrm{m}}<\eta_{\mathrm{o}}$ となることに表現されている。

図10に、 $\beta$ 型のBタイプについて、 $\mathrm{Kg}$ 一定での一体解析で得た隅 基礎および基礎固定の杭の $\mathrm{Mo} /\left(\mathrm{yoE}_{\mathrm{p}} \mathrm{I}_{\mathrm{p}}\right)$ - $\mathrm{sk}$ 関係を示した。隅基礎のMo $/\left(\mathrm{yoE} \mathrm{E}_{\mathrm{p}}\right)$ ) skに対する変化の様子は、基礎固定の場合の変化にほぼ比 例している。すでに、基礎固定の場合、 $\mathrm{Mo} /\left(\mathrm{yoE}_{\mathrm{p}} \mathrm{I}_{\mathrm{p}}\right)$ のskに対する変 化は $\beta_{0}$ の関係式として表せることから、基碄固定の曲線とほぼ同じ 変化をする隅基礎の曲線も $\beta_{\mathrm{o}}$ の関係式として表せると推定できる。 しかも、 $\mathrm{sk}=0$ では $\beta_{2}$ の 1 層地盤での杭基礎の值すなわち $(-2+2 \theta) \times \beta_{2}{ }^{2}$ であり、sk>2では $\beta_{1}$ の1層地盤での杭基礎の值 $(-2+2 \theta) \times \beta_{1}{ }^{2}$ であっ て、この間を $\beta_{0}$ の関係式として推移してゆくことを考えれば、その 近似的な式としては $(-2+2 \theta) \times \beta_{0}{ }^{2}$ が考えられる。 $\mathrm{sk}=0$ および>2の範

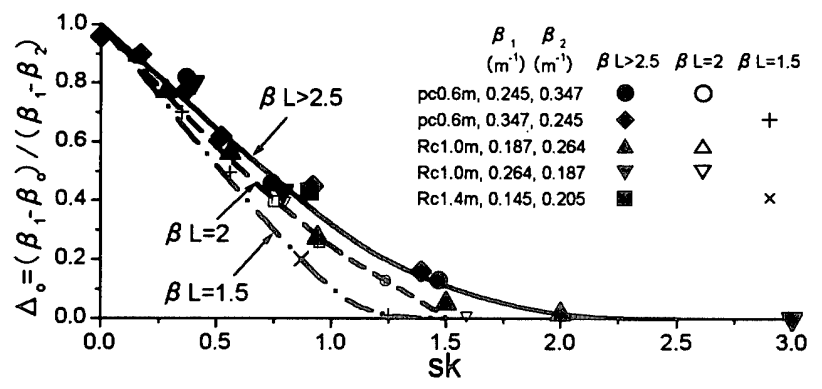

图6 等価地艋定数 $\beta$ 。一無次元層境界深さskの関倸 ( $\beta$ 型の杭頭曲げモーメントについて)

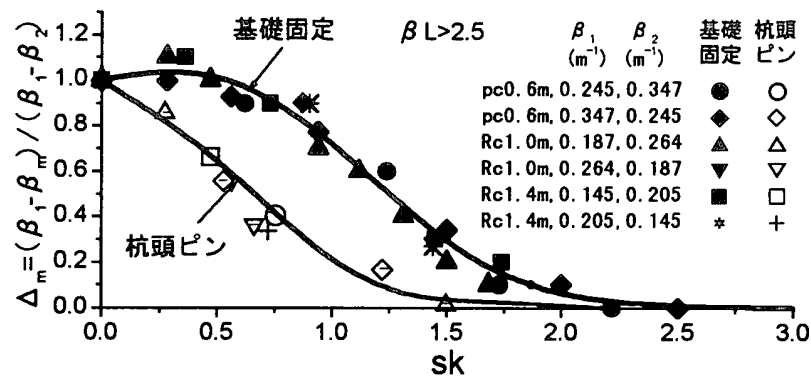

図8 等価地盤定数 $\beta_{\mathrm{m}}$-無次元層境界哚さskの関係 ( $\beta$ 型の地中部最大曲げモーメントについて)
囲では、 $\omega$ 值は(6)、(7)式で、 $\theta$ 值は1層地盤での $\theta-\omega$ 関係で表せ ることから、 $0<\mathrm{sk}<2$ の範囲では、 $\beta_{\mathrm{o}}$ を(6)、(7)式に適用して $\omega$ 值を 求め、1層地盤での $\theta-\omega$ 関倸によって $\theta$ 值を得ればよいと推定され る。以上に基づいて杭基整の等価式を(24)、(25)式に示した。图10に、 同等価式による隅基整の值を破線で併記したが、解析值とよく一致 しており、以上の考察が裹付けられた。なお、解析による2層地盤で の $\theta 0-\omega$ 関係図の記載は省略するが、sk一定でのこれらの曲線は1 層地盤の $\theta-\omega$ 関倸に比例的であるもののA・Bタイプでは異なる曲 線であったため、無次元回転角を $\theta \mathrm{o} /\left(\mathrm{yo}^{\circ} \beta_{\mathrm{o}}\right)-\omega$ 等の一般特性として 示すことはできなかった。

杭基礎: $\mathrm{Mo} /\left(\mathrm{yoE}_{\mathrm{p}} \mathrm{I}_{\mathrm{p}}\right)=(-2+2 /(2 \omega+1)) \times \beta_{\mathrm{o}}{ }^{2}$ $\mathrm{Mo} /\left(\mathrm{yoE}_{\mathrm{p}} \mathrm{I}_{\mathrm{p}}\right)=(-1+1.5 /(4.5 \omega+1.6)) \times \eta_{\mathrm{o}}{ }^{2}$

杭基礎の地中部最大曲げモーメントに関して、 $\mathrm{M}_{\mathrm{m}} /\left(\mathrm{yo} \mathrm{E}_{\mathrm{p}} \mathrm{I}_{\mathrm{p}}\right)$ は数式 で表現し難いので、 $\mathrm{Mo} /\left(\mathrm{yoE}_{\mathrm{p}} \mathrm{I}_{\mathrm{p}}\right)-\mathrm{M}_{\mathrm{m}} /\left(\mathrm{yoE}_{\mathrm{p}} \mathrm{I}_{\mathrm{p}}\right)$ 関係図を利用して求め る方法を図11〜图14に示す。対象とする2層地盤は、上、下層の地 盤定数が $\beta_{1}$ および $\beta_{2}\left(\eta_{1}\right.$ および $\left.\eta_{2}\right)$ である。まず、 $\beta_{1}$ あるいは $\beta_{2}\left(\eta_{1}\right.$

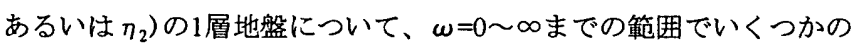
適当な $\omega$ 值を選び、この $\omega$ に対する $\left(\mathrm{Mo} /\left(\mathrm{yoE}_{\mathrm{p}} \mathrm{I}_{\mathrm{p}}\right), \mathrm{M}_{\mathrm{m}} /\left(\mathrm{yoE}_{\mathrm{p}} \mathrm{I}_{\mathrm{p}}\right)\right.$ を(10)あ るいは(11)式で求め、これらを結ぶと上下それぞれの限界曲線が得 られる。この限界曲線上に、対象とする杭基礎の基礎梁剛度 $\mathrm{Kg}$ 用 いて、 $\beta_{1}$ あるいは $\beta_{2}\left(\eta_{1}\right.$ あるいは $\left.\eta_{2}\right)$ の1層地盤での $\omega$ 值を(6) (9) 式で求め、 $\omega$ 值に対応する $\mathrm{Mo} /\left(\mathrm{yo} \mathrm{E}_{\mathrm{p}} \mathrm{I}_{\mathrm{p}}\right)$ 值の位置に印を記す。ここ で、当該2層地盤での無次元厚さを $\mathrm{sk}_{\mathrm{pec}}$ で再度記号化する。この $\mathrm{sk}_{\mathrm{pec}}$ に対応する $\mathrm{M}_{\mathrm{m}} /\left(\mathrm{yoE}_{\mathrm{p}} \mathrm{I}_{\mathrm{p}}\right)$ 値を(18)あるいは(19)式で得、その位置を左の 限界直線上に○印する。さらに、sk=0〜2（ $\eta$ 型はsk=0〜2.5）の範囲で 適当なsk值を選び、このskに対して(16)あるいは(17)式で $\mathrm{Mo} /\left(\mathrm{yoE}_{\mathrm{p}} \mathrm{I}_{\mathrm{p}}\right)$ および $\mathrm{M}_{\mathrm{m}} /\left(\mathrm{yoE}_{\mathrm{p}} \mathrm{I}_{\mathrm{p}}\right)$ 值を求め、これらを結べば右の限界曲線が得られ る。この曲線上に、 $\mathrm{sk}_{\mathrm{pec}}$ に対応する $\mathrm{Mo} /\left(\mathrm{yoE}_{\mathrm{p}} \mathrm{L}_{\mathrm{p}}\right) 、 \mathrm{M}_{\mathrm{m}} /\left(\mathrm{yoE}_{\mathrm{p}} \mathrm{I}_{\mathrm{p}}\right)$ 値を○印 で記す。印間を右の限界曲線なりに結び、またの印間を上下の限 界曲線なりに結ぶと、これらの交点が2層地盤の杭基磷の值にあたる

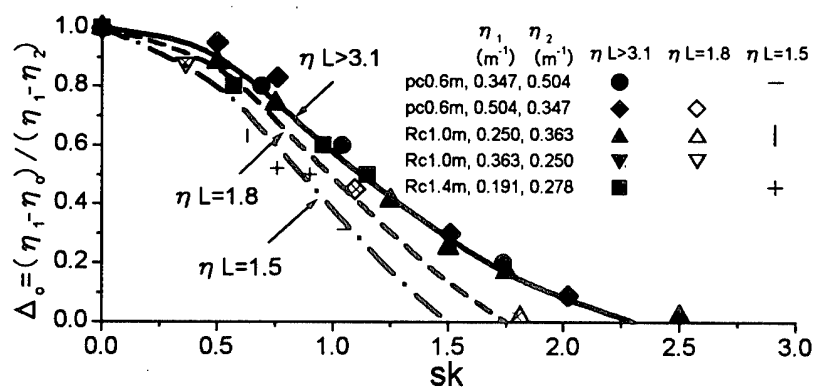

图7 等価地盤定数 $\eta_{\mathrm{o}}$ 一無次元層境界哚さskの関係 ( 型の杭頭曲げモーメントについて)

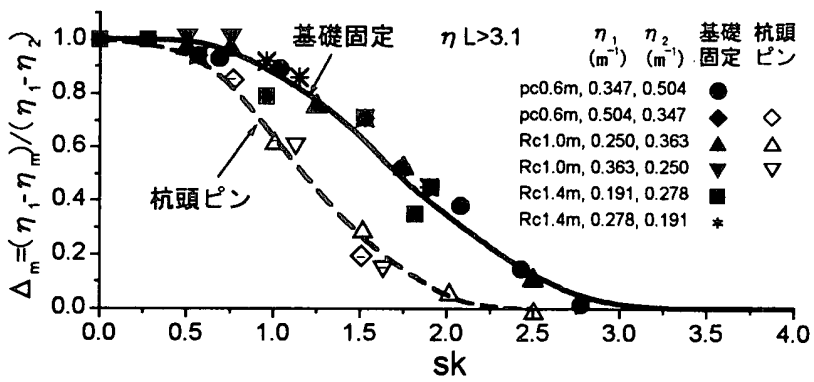

図9 等価地盤定数 $\eta_{\mathrm{m}}$ 一無次元層境界哚さ $\mathrm{sk}$ の関俰 ( $\eta$ 型の地中部最大曲げモーメントについて) 
ので、この交点の值を読みとればよい。あらかじめ、当該杭基礎の $\mathrm{Mo} /\left(\mathrm{yoE}_{\mathrm{p}} \mathrm{I}_{\mathrm{p}}\right)$ 值は(24)、(25)式で得られるので、交点をこの值に一致す るように曲線を修正すれば、より解析值に近い $\mathrm{M}_{\mathrm{m}} /\left(\mathrm{yoE}_{\mathrm{p}} \mathrm{I}_{\mathrm{p}}\right)$ 值が得ら れる。図5に、(24)、(25)式で計算した $\mathrm{Mo} /\left(\mathrm{yoE}_{\mathrm{p}} \mathrm{I}_{\mathrm{p}}\right)$ 値、および上記の 図法で得られる $\mathrm{M}_{\mathrm{m}} /\left(\mathrm{yoE}_{\mathrm{p}} \mathrm{I}_{\mathrm{p}}\right)$ 值を一点鎖線で示したが、解析結果とよ

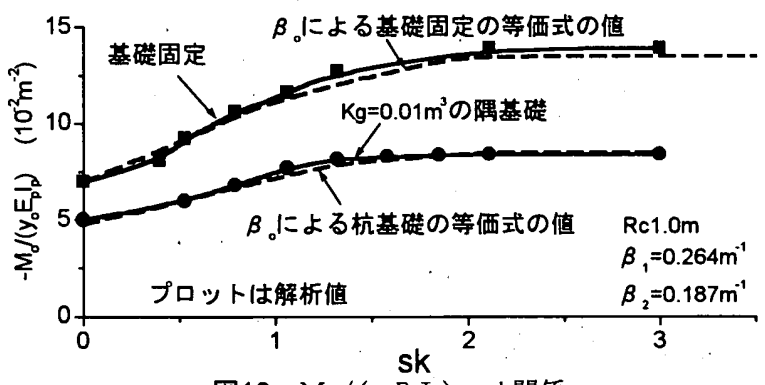

図10 $\mathrm{Mo} /\left(\mathrm{yoE}_{\mathrm{p}} \mathrm{I}_{\mathrm{p}}\right)-\mathrm{sk}$ 関係

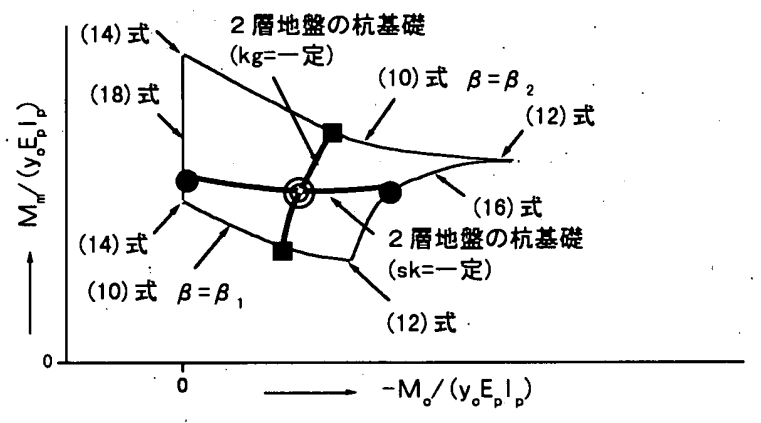

図11 杭頭曲げモーメントー地中部最大曲げモーメント関俰 ( $\beta$ 型 Aタイプ)

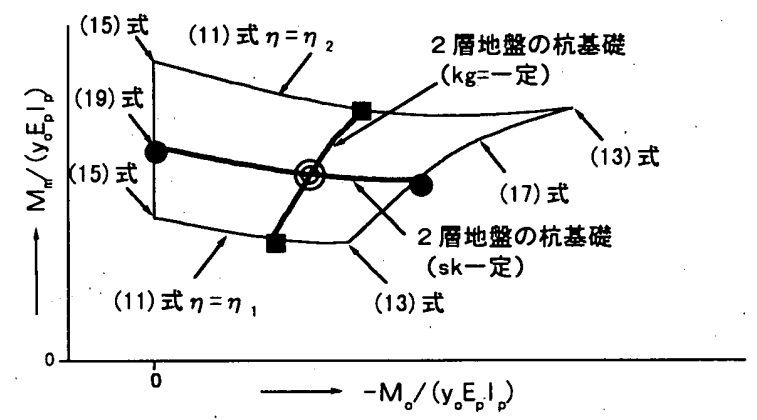

図13 杭頭曲げモーメントー地中部最大曲げモーメント関係 ( $\eta$ 型 $\mathrm{A}$ タイプ)

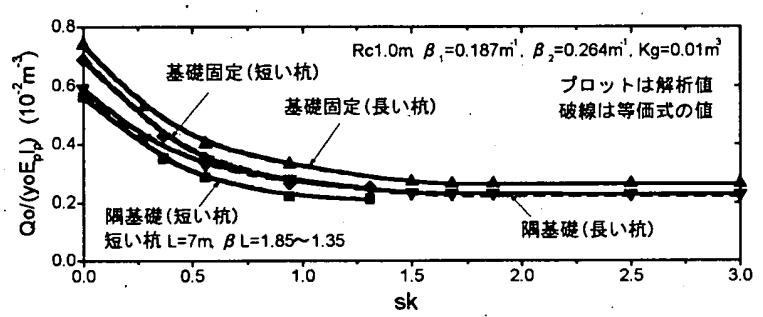

图15 杭頭水平力ー無次元層境界深さ関係 ( $\beta$ 型Aタイプ)

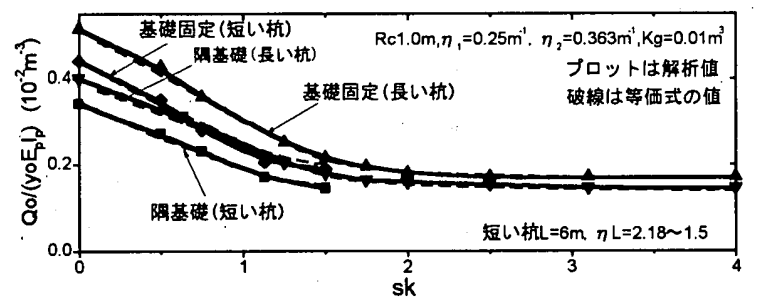

图17 杭頭水平力ー無次元層境界哚さ関係 ( $\eta$ 型Aタイプ)
く一致している。 $\beta$ 型のその他の事例でも計算値ノ解析値は $1.0 \pm 0.07$ 程度の範囲であり、 $\eta$ 型ではこれよりやや良い一致をみた。

\section{2 杭頭水平カについて}

解析で得た2層地盤における基礎固定の杭の $\mathrm{Qo} /\left(\mathrm{yoE}_{\mathrm{p}} \mathrm{I}_{\mathrm{p}}\right)$ - sk関係を、 $\beta$ 型、 $\eta$ 型のA、Bタイプにわけて図15〜図18にプロットし、実線 で結んでおいた。 $\mathrm{Qo} /\left(\mathrm{yoE} \mathrm{E}_{\mathrm{p}} \mathrm{I}_{\mathrm{p}}\right)$ は、sk=0では $\beta_{2}$ あるいは $\eta_{2}$ の 1 層地盤

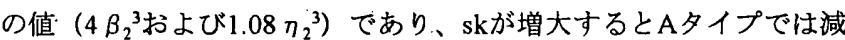

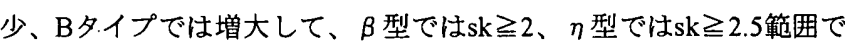
$\beta_{1}$ および $\eta_{1}$ の1層地盤の值 $\left(4 \beta_{1}{ }^{3}\right.$ および $\left.1.08 \eta_{1}{ }^{3}\right)$ に一致する。この 間のskの変化に対する $\mathrm{Qo} /\left(\mathrm{yoE}_{\mathrm{p}} \mathrm{I}_{\mathrm{p}}\right)$ 值の変化は、 $\beta$ 型はskが小さい程変 化の程度が大きいが、 $\eta$ 型はほぼk<0.5の範囲では緩やかに変化し、 $0.5<\mathrm{sk}<1$ 間で変化の程度がやや大きく、1<sk<2.5の間は再び緩やか になるといった、わずかにS字型の変化をする。

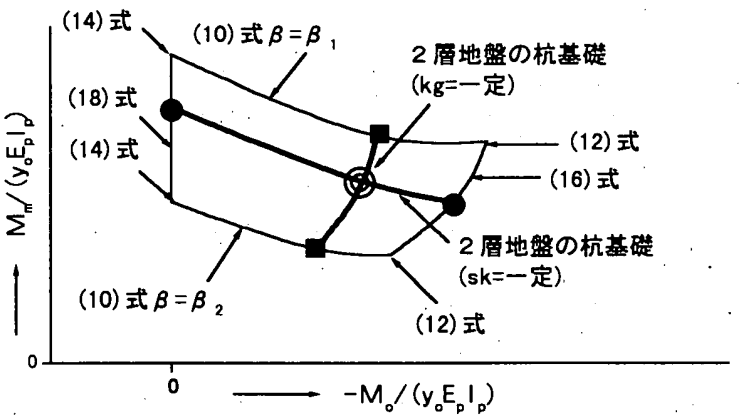

图12 杭頭曲げモーメントー地中部最大曲げモーメント関係 ( $\beta$ 型 Bタイプ $)$

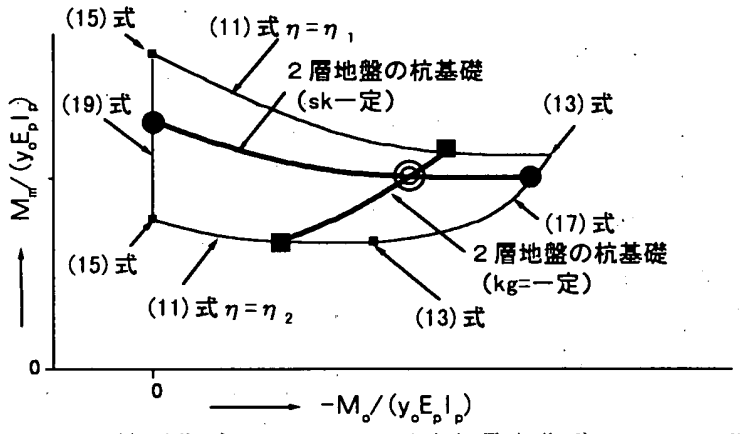

图14 杭頭曲げモーメントー地中部最大曲げモーメント関係 ( $\eta$ 型 Bタイプ $)$

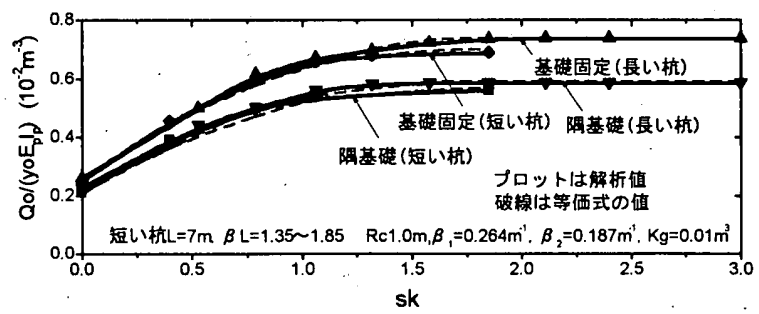

図16 杭頭水平力ー無次元層境界深さ関係 ( $\beta$ 型Bタイプ)

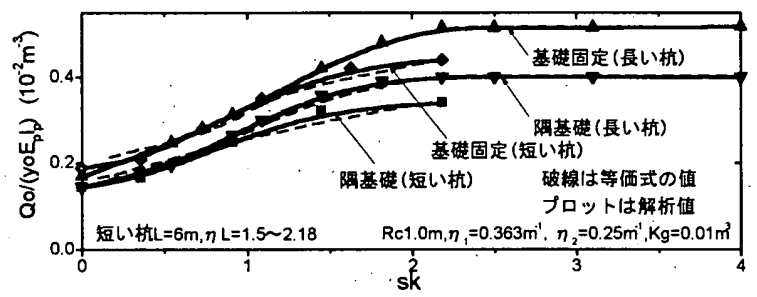

図18 杭頭水平力ー無次元層境界深さ関係 $(\eta$ 型B外・゚ 
以上のQo/(yoE $\left.\mathrm{E}_{\mathrm{p}} \mathrm{I}_{\mathrm{p}}\right)$ 値の一般特性は、 $\mathrm{Koz}^{\prime}$ 等の係数の一般特性が判 明しないので、(2)式あるいは(4)式によって考察することは難しい。 そこで、Qoに関しても2層地盤を1層地盤に置換する。Qoに関する等 価地盤定数を $\beta_{\mathrm{a}} 、 \eta_{\mathrm{a}}$ で記号化する。 $\beta_{\mathrm{a}} 、 \eta_{\mathrm{a}}$ は、2層地盤において基 堡固定の解析で得た $\mathrm{Qo} / \mathrm{yo}$ 值を 1 層地盤の式に代入して、 $\beta_{\mathrm{a}}=(\mathrm{Qo} /(4 \mathrm{yo}$ $\left.\left.\mathrm{E}_{\mathrm{p}} \mathrm{I}_{\mathrm{p}}\right)\right)^{1 / 3} 、 \eta_{\mathrm{a}}=\left(\mathrm{Qo} /\left(1.08 \mathrm{yo} \mathrm{E}_{\mathrm{p}} \mathrm{I}_{\mathrm{p}}\right)\right)^{1 / 3}$ で得た。これを $\Delta_{\mathrm{a}}=\left(\beta_{1}-\beta_{\mathrm{a}}\right) /\left(\beta_{1}-\beta_{2}\right)$ および $\left(\eta_{1}-\eta_{\mathrm{a}}\right) /\left(\eta_{1}-\eta_{2}\right)$ で無次元化し、 $\Delta_{\mathrm{a}}-\mathrm{sk}$ 関係を図19、図20に 示したが、ほほskで一義的にきまる曲線関係 (同図実線)であったの で、 $\beta_{\mathrm{a}} 、 \eta_{\mathrm{a}}$ は(26)、(27)式で表せた。この $\beta_{\mathrm{a}} 、 \eta_{\mathrm{a}}$ を用いて基礎固定 の杭のQo/(yoE $\left.\mathrm{f}_{\mathrm{p}}\right)$ ) (28)、(29)式で表せる。 $\Delta_{\mathrm{a}}$ 值を表4に示した。

図15〜図18に、長い杭基礎についての一体解析值のうち隅基礎の $\mathrm{Qo} /\left(\mathrm{yoE}_{\mathrm{p}} \mathrm{I}_{\mathrm{p}}\right)$ 值を併記した。隅基礎のQo/( $\left.\mathrm{yoE}_{\mathrm{p}} \mathrm{I}_{\mathrm{p}}\right)$ - sk曲線は、基䃈固定 のo/(yoE $\left.\mathrm{E}_{\mathrm{p}} \mathrm{I}_{\mathrm{p}}\right)$-sk曲線にほぼ比例的な変化をしていることから、基整 固定の杭と同様にその変化は $\beta_{\mathrm{a}} 、 \eta_{\mathrm{a}}$ の関係式として表せると推定で きる。しかも、 $\mathrm{sk}=0$ では、1層地盤の杭基礎の值(4-2 $\theta) \times \beta_{2}{ }^{3}$ あるい

表4 $\Delta$ 。

\begin{tabular}{|l|l|l|}
\hline \multicolumn{1}{|c|}{ sk } & \multicolumn{1}{c|}{$\beta$ 型 } & \multicolumn{1}{c|}{$\eta$ 型 } \\
\hline 0 & 1.0 & 1.0 \\
\hline 0.5 & 0.44 & 0.8 \\
\hline 1.0 & 0.13 & 0.44 \\
\hline 1.5 & 0.03 & 0.2 \\
\hline 2.0 & 0 & 0.08 \\
\hline 2.5 & 0 & 0 \\
\hline
\end{tabular}

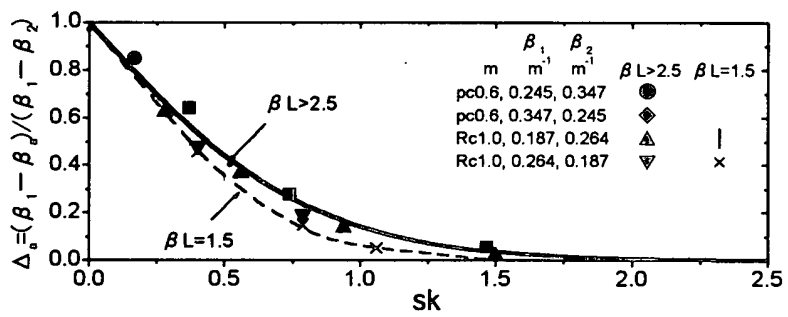

図19等価地艋定数 $\beta_{\mathrm{a}}$ と層境界深さの関係 ( $\beta$ 型の杭頭水平力に関して)

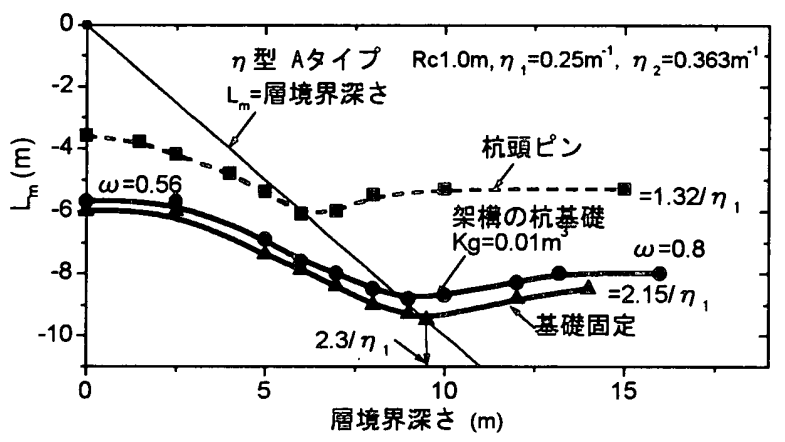

图21 地中部最大曲げモーメント発生梁さ一層境界深さ(Aタイプ)

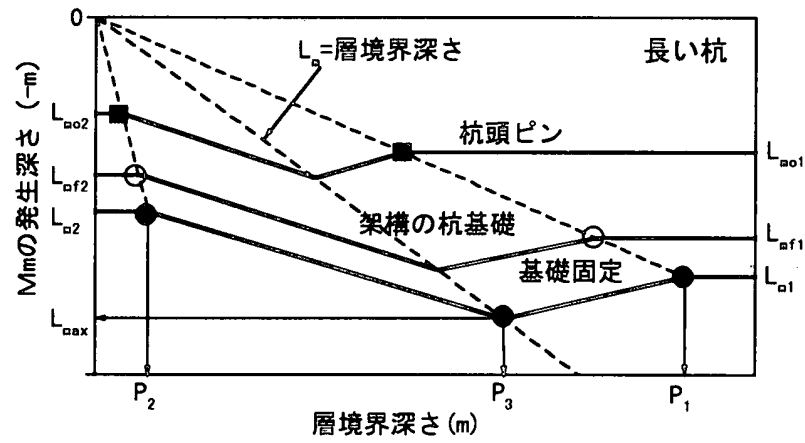

図23地中部最大曲げモーメント発生深さ一層境界媣さ(Aタイプ)
は(1.08- $\theta) \times \eta_{2}{ }^{3}$ に一致し、 $\beta$ 型のsk $\geqq 2 て ゙ は(4-2 \theta) \times \beta_{1}{ }^{3} 、 \eta$ 型のsk $\geqq 2.5$ では(1.08- $\theta) \times \eta_{1}{ }^{3}$ の1層地盤の杭基礎の值に一致することから、 $0<\mathrm{sk}<2 （ \eta$ 型は $0<\mathrm{sk}<2.5 ）$ 間の杭基礎のQo/ $\left(\mathrm{yoE}_{\mathrm{p}} \mathrm{I}_{\mathrm{p}}\right)$ 変化も、1層地 盤の杭基礎の式の $\beta=\beta_{\mathrm{a}} 、 \eta=\eta_{\mathrm{a}}$ とした $(30)$ 、(31)式で表せると考え られる。なお、 $\omega$ は $\mathrm{Mo} /\left(\mathrm{yoE}_{\mathrm{p}} \mathrm{I}_{\mathrm{p}}\right)$ における $\beta_{\mathrm{o}} 、 \eta_{\mathrm{o}}$ を(6)〜(9)式に適用 した值とし、 $\theta$ は1層地盤の $\theta-\omega$ 関係によるものとする。これらの 等価式による值は図15〜図18に破線で示すように解析值とよく一致 する。その他の $\beta$ 型、 $\eta$ 型およびA、Bタイプについての計算値/解 析値は、 $1.0 \pm 0.05$ 程度であった。

Qoに関する等価地盤定数 : $\beta_{\mathrm{a}}=\beta_{1}-\Delta_{\mathrm{a}} \times\left(\beta_{1}-\beta_{2}\right)$

$$
\eta_{\mathrm{a}}=\eta_{1}-\Delta_{\mathrm{a}} \times\left(\eta_{1}-\eta_{2}\right)
$$

基礎固定： $\mathrm{Qo} /\left(\mathrm{yoE}_{\mathrm{p}} \mathrm{I}_{\mathrm{p}}\right)=4 \beta_{\mathrm{a}}{ }^{3}$

$\mathrm{Qo} /\left(\mathrm{yoE}_{\mathrm{p}} \mathrm{I}_{\mathrm{p}}\right)=1.08 \eta_{\mathrm{a}}{ }^{3}$

表5 層境界深さ $\ell_{1}(\mathrm{~m})$ と $\mathrm{M}_{\mathrm{m}}$ の発生深さ $\mathrm{L}_{\mathrm{m}}(\mathrm{m})$

\begin{tabular}{|c|c|c|c|c|}
\hline & \multicolumn{2}{|c|}{$\beta$ 型2層地盤 } & \multicolumn{2}{|c|}{$\eta$ 型2層地盤 } \\
\hline & $\ell$ & $\mathrm{L}_{\mathrm{m}}$ & $\ell$ & $\mathrm{L}_{\mathrm{m}}$ \\
\hline \multirow{2}{*}{ A,B共通 } & $P_{1}=2.5 / \beta_{1}$ & $\mathrm{~L}_{\mathrm{m}}=1.57 / \beta_{1}$ & $P_{d}=3.1 / \eta_{1}$ & $\mathrm{~L}_{\mathrm{ml}}=2.15 / \eta_{\mathrm{L}}$ \\
\hline & $\mathrm{P}_{2}=0.2 / \beta_{2}$ & $\mathrm{~L}_{\mathrm{m} 2}=1.57 / \beta_{2}$ & $P_{2}=0.7 / \eta_{2}$ & $\mathrm{~L}_{\mathrm{m} 2}=2.15 / \eta_{2}$ \\
\hline Aタイプ & $P_{3}=1.74 / \beta$ & $\mathrm{L}_{\max }=1.74 / \beta_{\mathrm{A}}$ & $P_{3}=2.3 / \eta_{1}$ & $\mathrm{~L}_{\max }=2.3 / \eta_{1}$ \\
\hline Bタイプ & $P_{3}=1.4 / \beta_{1}$ & $\mathrm{~L}_{\min }=1.4 / \beta_{1}$ & $P_{3}=1.9 / \eta_{1}$ & $L_{\min }=1.9 / \eta_{1}$ \\
\hline \multirow{2}{*}{ A,B共通 } & - & $\mathrm{L}_{\mathrm{ma}}=\mathrm{d} / \beta_{1}$ & - & $\mathrm{L}_{\mathrm{mfl}}=\mathrm{d}_{d} / \eta_{1}$ \\
\hline & - & $\mathrm{L}_{\mathrm{mD}}=\mathrm{d}_{\mathrm{d}} / \beta_{2}$ & - & $\mathrm{L}_{\mathrm{m} \ell}=\mathrm{d}_{\mathrm{d}} / \eta_{2}$ \\
\hline
\end{tabular}

注) $d_{o}$ は表6の值

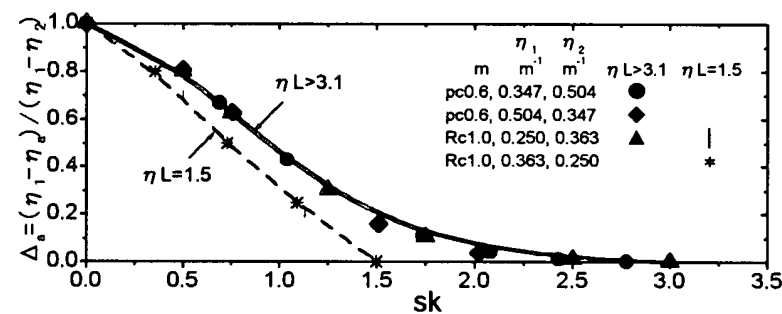

図20 等価地盤定数 $\eta_{\mathrm{a}}$ と層境界深さの関係 $(\eta$ 型の杭頭水平力に関して)

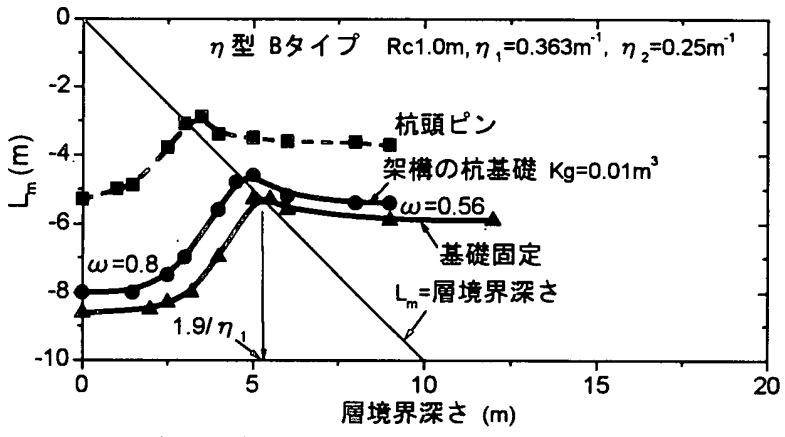

図22 地中部最大曲げモーメント発生深さ一層境界深さ (Bタイプ)

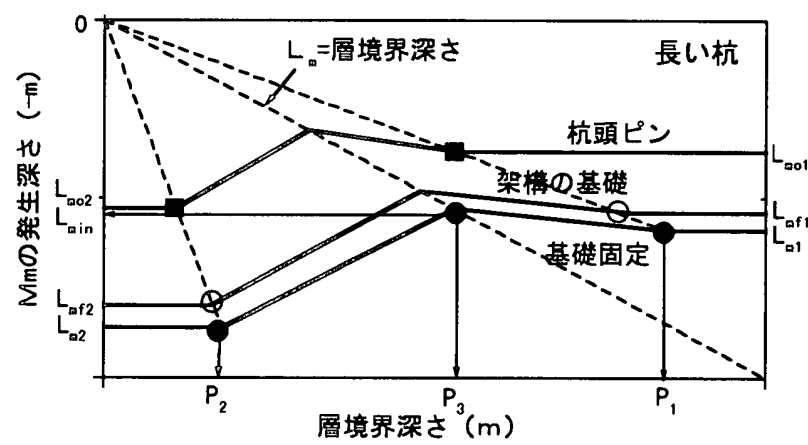

図24地中部最大曲げモーメント発生深さ一層境界深さ (Bタイプ) 
杭基礎： $\quad \mathrm{Qo} /\left(\mathrm{yoE}_{\mathrm{p}} \mathrm{I}_{\mathrm{p}}\right)=(4-2 /(2 \omega+1)) \times \beta_{\mathrm{a}}{ }^{3}$

$\mathrm{Qo} /\left(\mathrm{yoE} \mathrm{E}_{\mathrm{p}} \mathrm{I}_{\mathrm{p}}\right)=(1.08-1 /(4.5 \omega+1.6)) \times \eta_{\mathrm{a}}{ }^{3}$

以上の等価式によって、杭基礎のQo、Mo、 $\mathrm{M}_{\mathrm{m}}$ は以下の方法で計算 できる。それぞれの杭基礎のQo/(yoE $\mathrm{E}_{\mathrm{p}}$ ) 值は(30)あるいは(31)式で計 算し、これに $\mathrm{E}_{\mathrm{p}} \mathrm{I}_{\mathrm{p}}$ を乗じて杭頭水平剛性Qo/yoを得る。Qo/yoを架構の 全ての杭について合計し、これを $\Sigma \mathrm{Qo} / \mathrm{yo}$ で記号化する。杭頭水平変 位yoは全ての杭について等しいので、基礎全体に作用する水平力Qall おうよび $\Sigma \mathrm{Qo} / \mathrm{yo}$ 用いて(32)式で計算出来る。杭頭曲げモーメントに 関する $\mathrm{Mo} /\left(\mathrm{yo} \mathrm{E}_{\mathrm{p}} \mathrm{I}_{\mathrm{p}}\right)$ は(24)あるいは(25)式で計算し、また地中部最大曲 げモーメントは図11〜図14の $\mathrm{Mo} /\left(\mathrm{yoE}_{\mathrm{p}} \mathrm{I}_{\mathrm{p}}\right)-\mathrm{M}_{\mathrm{m}} /\left(\mathrm{yoE}_{\mathrm{p}} \mathrm{I}_{\mathrm{p}}\right)$ 曲線図を作成 することによって、その交点として值が得られる。これらの值にyoお よびE $\mathrm{p}_{\mathrm{p}} \mathrm{I}_{\mathrm{p}}$ 乗じると、各杭基礎に生じる杭頭水平力Qo、曲げモーメン トMoおよび地中部最大曲げモーメント $\mathrm{M}_{\mathrm{m}}$ 值が得られる。

$$
\begin{aligned}
& \text { yo=Qall } /(\Sigma \mathrm{Qo} / \mathrm{yo}) \\
& \mathrm{Qo}=\mathrm{Qo} /\left(\mathrm{yoE}_{\mathrm{p}} \mathrm{I}_{\mathrm{p}}\right) \times \text { yo } \times \mathrm{E}_{\mathrm{p}} \mathrm{I}_{\mathrm{p}} \\
& \mathrm{Mo}=\mathrm{Mo} /\left(\mathrm{yoE}_{\mathrm{p}} \mathrm{I}_{\mathrm{p}}\right) \times \text { yo } \times \mathrm{E}_{\mathrm{p}} \mathrm{I}_{\mathrm{p}} \\
& \mathrm{M}_{\mathrm{m}}=\mathrm{M}_{\mathrm{m}} /\left(\mathrm{yoE}_{\mathrm{p}} \mathrm{I}_{\mathrm{p}}\right) \times \text { yo } \times \mathrm{E}_{\mathrm{p}} \mathrm{I}_{\mathrm{p}}
\end{aligned}
$$

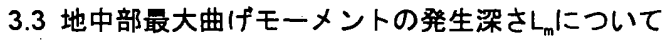

$\eta$ 型でAおよびBタイプの2層地盤について、解析で得た $\ell_{1}-\mathrm{L}_{m}$ 関 係の一例を図21、図22に示した。基礎固定の場合、 $\ell_{1}(\mathrm{~m})$ が增大寸 ると、 $\mathrm{L}_{\mathrm{m}}$ は $\mathrm{A}$ タイプでは増大して最大深さ $\mathrm{L}_{\max }$ に達し、Bタイプでは

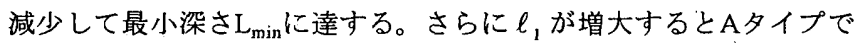
は堿少、Bタイプでは増大に転じて、いずれの場合も $\eta_{1}$ の層地盤で の梁さに一致する。本解析の範囲での $\mathrm{L}_{\max } 、 \mathrm{~L}_{\min }$ は表5の值であった。 同表の算定式の係数 $\mathrm{d}_{\mathrm{O}}$ は表6の值であって、 $\omega$ 值は、 $\mathrm{L}_{\mathrm{m} \Omega}$ に対しては(6) $\sim(9)$ 式で $\beta=\beta_{1} 、 \eta=\eta_{1}$ として求め、 $\mathrm{L}_{\mathrm{me}}$ に対しては $\beta=\beta_{2} 、 \eta=\eta_{2}$ と して求める。なお、 $\mathrm{L}_{\max } 、 \mathrm{~L}_{\min }$ の場合のみ、 $\mathrm{M}_{\mathrm{m}}$ の発生深さは $\ell_{1} に 一$ 致するが、これ以外は層境界以外に発生する。ここに、而あるいは $\eta_{2}$ の1層地盤での発生深さに比べ、2層地盤での $\mathrm{L}_{\max }$ が大きく $\mathrm{L}_{\min }$ が小 さいのは以下の理由による。 $\mathrm{M}_{\mathrm{m}}$ は杭体せん断力が0の深さで発生す るが、Aタイプでは上層の地盤反力が小さいので1層地盤よりも深く なり、Bタイプでは上層の地盤反力が大きいので1層地盤より.も浅く なるためである。以上の関係は図23、図24の折れ線で近似でき、ま た図21、図22において杭基礎の $\ell_{1}-\mathrm{L}_{\mathrm{m}}$ は基礎固定の曲線に比例的

\begin{tabular}{|c|c|}
\hline $\mathrm{L}_{\mathrm{ml}}$ & $\beta_{1}$ あるいは $\eta_{1}$ の1層地盤における基礎固定の杭の $\mathrm{L}_{\mathrm{m}}(\mathrm{m})$ \\
\hline $\mathrm{L}_{\mathrm{m} 2}$ & $\beta_{2}$ あるいは $\eta_{2}$ の1層地盤における基礎固定の杭の $L_{\mathrm{m}}(\mathrm{m})$ \\
\hline $\mathrm{L}_{\mathrm{mfl}}$ & $\beta_{1}$ あるいは $\eta_{1}$ の層地盤における杭基礎の $\mathrm{L}_{\mathrm{m}}(\mathrm{m})$ \\
\hline $\mathrm{L}_{\mathrm{mf} 2}$ & $\beta_{2}$ あるいは $\eta_{2}$ の層地盤における杭基礎の $\mathrm{L}_{\mathrm{m}}(\mathrm{m})$ \\
\hline $\mathrm{L}_{\text {mol }}$ & $\beta_{1}$ あいは $\eta_{1}$ の層地盤における杭頭ピンの杭の $\mathrm{L}_{\mathrm{m}}(\mathrm{m})$ \\
\hline $\mathrm{L}_{\mathrm{mo2}}$ & $\beta_{2}$ あいは $\eta_{2}$ の層地盤における杭頭ピンの杭の $\mathrm{L}_{\mathrm{m}}(\mathrm{m})$ \\
\hline$P_{1}$ & $\begin{array}{l}\text { 2層地盤において基礎固定の杭の } \mathrm{L}_{\mathrm{m}} \text { が } \mathrm{L}_{\mathrm{m}} \text { に一致する場合の } \\
\text { 曾境界哚さ } \ell_{1} \text { の最小值 }(\mathrm{m})\end{array}$ \\
\hline $\mathrm{P}_{2}$ & $\begin{array}{l}\text { 2層地盤において基礎固定の杭の } \mathrm{L}_{\mathrm{m}} \not ゙ \mathrm{~L}_{\mathrm{m} 2} に \text { 致する場合の } \\
\text { 層境界深さ } \ell_{1} \text { の最大值 }(\mathrm{m})\end{array}$ \\
\hline $\mathrm{P}_{3}$ & $\begin{array}{l}\text { 2層地盤において基礎固定の杭の } \mathrm{L}_{\mathrm{m}} \text { が } \mathrm{L}_{\max } \text { あるいは } \\
\text { る層境界深さ }(\mathrm{m})\end{array}$ \\
\hline
\end{tabular}
であることから、基礎梁剛度が任意の杭基礎の $\ell_{1}-\mathrm{L}_{\mathrm{m}}$ 関倸は、図23、 図24においで、1層地盤での $\mathrm{L}_{\mathrm{m} 2 、} 、 \mathrm{~L}_{\mathrm{mf}}$ 值 (○印) 間を基礎固定の折れ

表7 $\mathrm{L}_{\mathrm{m}}$ に関する記号説明
線に比例的に結んで得られる。各図の折れ点は記号で示し、表7に 記号の説明をしておいた。

\section{4. 短い杭基礎の杭頭曲げモーメントおよひ杭頭水平力特性}

杭長さLが短い場合について、ク型2層地盤での解析によって得た $\mathrm{Mo} /\left(\mathrm{yo} \mathrm{E}_{\mathrm{p}} \mathrm{I}_{\mathrm{p}}\right)-\mathrm{sk}$ 関係の一例を、図25に示した。 $\mathrm{Mo} /\left(\mathrm{yoE}_{\mathrm{p}} \mathrm{I}_{\mathrm{p}}\right)$ は、sk=0 では、 $\eta_{2}$ の1層地盤での值(基礎固定は-2Koy $\times \eta_{2}{ }^{2}$ 、杭基礎は(-2Koy $+2 \operatorname{Kom} \theta) \times \eta_{2}{ }^{2}$ )であって、skが增大するとAタイプでは堿少し、B

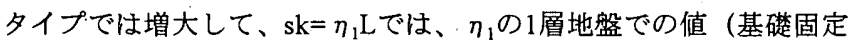
は-2Koy $\times \eta_{1}{ }^{2}$ 、杭基礎は (-2Koy+2Kom $\left.\left.\theta\right) \times \eta_{4}{ }^{2}\right)$ に一致する。この ような変化の様子は、すでに述べた長い杭の場合と類似している。 したがって、杭長さが短い場合についても、長い杭と同様の方法で 等価な1層地盤への置換が可能と考えられる。

短い杭のMoに関する等価地盤定数 $\beta$ 。、 $\eta_{0}$ は、基礎固定の解析で 得た $\mathrm{Mo} / \mathrm{yo}$ 值を短い杭の1層地盤の式に代入して、 $\beta_{0}$ および $\eta_{0}=(-\mathrm{Mo} /$ $\left.\left(2 \mathrm{Koy} \times \mathrm{yoE}_{\mathrm{p}} \mathrm{I}_{\mathrm{p}}\right)\right)^{1 / 2}$ で得た。これを、長い杭と同様に $\Delta_{\mathrm{o}}$ に無次元化し た。 一点鎖線で近似できたので、 $\beta_{0}$ および $\eta_{0}$ は(20)、(21)式で特定でき た。したがって、基礎固定の短い杭の解析值の等価式として、(37)、 (38)式が示せる。基礎固定と杭基礎の曲線の相似的な関係等を考慮 寸れば、短い杭基礎の $\mathrm{Mo} /\left(\mathrm{yoE}_{\mathrm{p}} \mathrm{I}_{\mathrm{p}}\right)$ )等価式も、1層地盤式の $\beta=\beta$ 、 $\eta=\eta_{0}$ とした式で表せると推測できる。これを(39)、(40)式に示した。 なお、無次元杭長さによってKoy、Komの係数值や $\theta-\omega$ 関係が異 なるので、山の関倸式とはせずにKoy、 $\theta$ などのまま表示した。こ こに、 $\omega$ は $\beta_{0} 、 \eta_{0}$ を(6) (9)式に適用した值とし、 $\theta$ は1層地盤の $\theta$ 一 $\omega$ あるいは $\theta-\beta \mathrm{L} 、 \theta-\eta \mathrm{L}$ 関係図 ${ }^{4)}$ の值を用いる。Koy等の值は 表1に例示した。等価式による隅基礎の值を破線で図25に示したが、 解析值の特性をほぼ表しているといえる。

$$
\begin{array}{ll}
\text { 基礎固定: } & \mathrm{Mo} /\left(\mathrm{yoE}_{\mathrm{p}} \mathrm{I}_{\mathrm{p}}\right)=-2 \mathrm{Koy} \times \beta_{\mathrm{o}}{ }^{2} \\
& \mathrm{Mo} /\left(\mathrm{yoE}_{\mathrm{p}} \mathrm{I}_{\mathrm{p}}\right)=-2 \mathrm{Koy} \times \eta_{\mathrm{o}}{ }^{2} \\
\text { 杭基礎 : } \quad \mathrm{Mo} /\left(\mathrm{yoE}_{\mathrm{p}} \mathrm{I}_{\mathrm{p}}\right)=(-\mathrm{Koy}+\mathrm{Kom} \times \theta) \times 2 \beta_{\mathrm{o}}{ }^{2}
\end{array}
$$

短い杭について、2層地盤での解析で得た $\mathrm{Qo} /\left(\mathrm{yoE} \mathrm{E}_{\mathrm{p}} \mathrm{I}_{\mathrm{p}}\right)$ と $\mathrm{sk}$ 関係を、 図15〜図18に併記した。隅基礎の関係曲線は基礎固定の関係曲線に ほほ比例的であって、また長い杭とも類似性が認められるので、短 い杭基礎のQoに関しても1層地盤への置換は可能と推定できる。等価 地盤定数 $\beta_{\mathrm{a}} 、 \eta_{\mathrm{a}}$ は、解析で得たQo/yo值を1層地盤での基礎固定の式 $4 \mathrm{Koz} \times \beta^{3} 、 4 \mathrm{Koz} \times \eta^{3}$ に代入して、 $\beta_{\mathrm{a}}$ および $\eta_{\mathrm{a}}=\left(\mathrm{Qo} /\left(4 \mathrm{Koz} \times \mathrm{yoE} \mathrm{E}_{\mathrm{p}} \mathrm{I}_{\mathrm{p}}\right)^{1 / 3}\right.$ で得た。これを、長い杭と同様の方法で $\Delta_{\mathrm{a}}$ に無次元化し、図19、図 20に併記したが、skとの関係はほぼ破線で示した曲線で近似できた

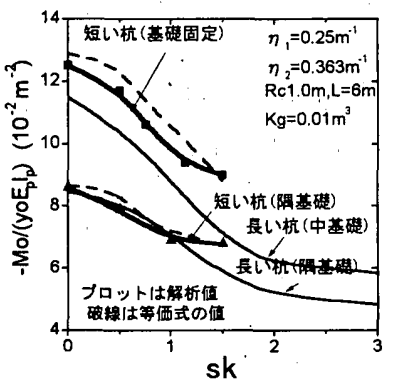

(Aタイプ)

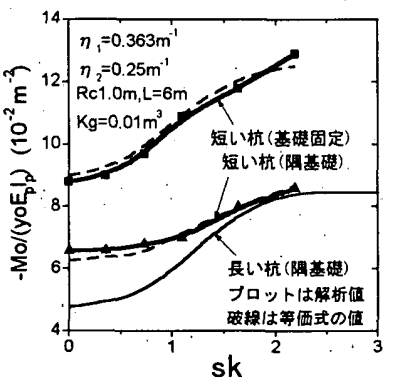

(Bタ.イプ)
図25 杭頭曲げモーメント一層境界深さ関倸(短い杭) 
ので、 $\beta_{\mathrm{a}} 、 \eta_{\mathrm{a}}$ は前述の(26)、(27)式で表せる。したがって、基礎固定 の短い杭のQo/(yoE $\left.\mathrm{E}_{\mathrm{p}} \mathrm{f}\right)$ の等価式は(41)、(42)式で表せる。杭基礎の等 価式も、1層地盤の短い杭基礎の式にこの $\beta_{\mathrm{a}} 、 \eta_{\mathrm{a}}$ を適用して(43)、(44) 式で表せる。等価式による值を図15～図18に破線で示したが、解析 值とよく一致している。

$$
\begin{aligned}
& \text { 基礎固定： } \mathrm{Qo} /\left(\mathrm{yoE} \mathrm{E}_{\mathrm{p}} \mathrm{I}\right)=4 \mathrm{Koz} \times \beta_{\mathrm{a}}{ }^{3} \\
& \mathrm{Qo} /\left(\mathrm{yoE}_{\mathrm{p}} \mathrm{I}_{\mathrm{p}}\right)=4 \mathrm{Koz} \times \eta_{\mathrm{a}}{ }^{3}
\end{aligned}
$$

杭基礎： $\quad \mathrm{Qo} /\left(\mathrm{yoE}_{\mathrm{p}} \mathrm{I}_{\mathrm{p}}\right)=(4 \mathrm{Koz}-2 \mathrm{Koy} \times \theta) \times \beta_{\mathrm{a}}{ }^{3}$

$\mathrm{Qo} /\left(\mathrm{yoE} \mathrm{E}_{\mathrm{p}} \mathrm{I}_{\mathrm{p}}\right)=(4 \mathrm{Koz}-2 \mathrm{Koy} \times \theta) \times \eta_{\mathrm{a}}{ }^{3}$

以上、長い杭、短い杭について、架構剛性の影響を考慮した杭基 礎の特性を、等価式および図によって説明した。任意の地盤条件お よび架構条件での杭基礎のMo、Qoおよびyo值は、これらの等価式 によって解析結果と比較的良く一致する值が得られる。2層地盤にお いて、架構の剛性を考慮した場合の杭基整の応力が、基礎固定の場 合とどのような相違があるかを图25(Aタイプ)で比べてみる。例え ば、上層が均一な厚さ $\mathrm{sk}=1$ の場合、隅基礎でかつ短い杭の $\mathrm{Mo} /\left(\mathrm{yoE}_{\mathrm{p}} \mathrm{I}_{\mathrm{p}}\right)$ は基礎固定の短い杭の值の約 $75 \%$ であり、中基礎の長い杭よりも約 10\%小さく、長い隅基礎とほぼ等しい。このことから、長い杭基礎 の応力が、比較的剛な短い杭基礎よりも小さいとは限らないこと、 短い杭基礎を基礎固定と仮定して応力を得ることは、過大な応力を 想定すること、従って、杭体の変形量および地盤の変形量にかなり 大きな誤差を生じる恐れのあること等がわかる。さらに、上層の層 厚が各基砶ごとに変化する場合は等価地盤定数が各基礎ごとで異な り、かつ架構のスパン長さが異なる場合では、基礎に集まる $\Sigma \mathrm{Kg}$ が 異なるため、各基礎の $\omega$ 、したがって $\theta$ も異なるので、各杭基礎の 応力や変形がどのようであるかはより複雑となる。このように、杭 基礎の応力・変形は、単に無次元杭長さの長・短や隅 - 中基礎の相 違からだけで推定できるものではないため、その概略值を知る上で も以上の等価式を用いた計算による検討が望まれる。

\section{5. 結論}

架構に水平力が作用した場合の杭基整について、地盤が多層状態 での応力・変形特性を系統的に明らかにした。方法は、架構と杭を 一体とした弾性解析であって、基礎梁剛度、杭種、杭径、杭長さお よび地盤定数などの組み合わせを変化させて解析した。杭への地盤 反力は線形の水平バネ定数で想定した。地盤の水平反力係数 $\mathrm{k}_{\mathrm{h}}$ が定の場合を $\beta$ 型、 $\mathrm{k}_{\mathrm{h}}$ が深さに比例する場合を $\eta$ 型と称し、上層地盤

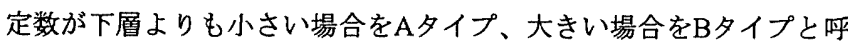
んだ。以下、杭頭水平力Qo、杭頭曲げモーメントMo、地中部最大曲 げモーメント $\mathrm{M}_{\mathrm{m}}$ 、杭頭水平変位yo、杭の曲け剛性 $\mathrm{E}_{\mathrm{p}} \mathrm{I}_{\mathrm{p}}$ 、杭頭回転拘束 度 $\omega$ 、地盤の境界深さの無次元量skで記号化する。解析の結果、2層 地盤における架構の杭基礎の応力・変形は、各基礎における杭径の 相違、無次元杭長さの相違、地盤条件あるいは架構の基礎梁剛性さ らには隅、中基䊙の違いといった諸条件の影響を複雑に受けること がわかった。その一般特性として以下を明らかにした。

（1）杭基礎の応力、変形の共通特性は、その絶対量でなく、単位水 平変位あたりの $\mathrm{Mo} /\left(\mathrm{yoE}_{\mathrm{p}} \mathrm{I}_{\mathrm{p}}\right) 、 \mathrm{Qo} /\left(\mathrm{yoE}_{\mathrm{p}} \mathrm{I}_{\mathrm{p}}\right) 、 \mathrm{M}_{\mathrm{m}} /\left(\mathrm{yoE}_{\mathrm{p}} \mathrm{I}_{\mathrm{p}}\right)$ に表れ、隅・中 基礎の相違は $\omega$ によって表現できる。

(2) skが変化する場合の $\mathrm{Mo} /\left(\mathrm{yoE}_{\mathrm{p}} \mathrm{I}_{\mathrm{p}}\right)-\mathrm{M}_{\mathrm{m}} /\left(\mathrm{yoE}_{\mathrm{p}} \mathrm{I}_{\mathrm{p}}\right)$ 関係は、2層地盤は ほほ棈円の線上にあり、1層地盤はこの棈円を貫く直線である。多層
地盤は棈円内にあって、多層になるほど1層に収斂するので、杭基礎 の応力/変形への層序の影響は2層の場合に最も顕著に現れる。

(3) 長い杭（ $\beta \mathrm{L}>2.5 、 \eta \mathrm{L}>3.1 ）$ において2層性を考慮すべき範囲 は $\beta$ 型 $: \mathrm{sk}<2 、 \eta$ 型 : sk<2.5である。これ以外は、杭全長にわたっ て上層地盤が広がった1層地盤に等しい。

(4) 2 層地盤の杭基礎のQo/ $\left(\mathrm{yoE}_{\mathrm{p}} \mathrm{I}_{\mathrm{p}}\right) 、 \mathrm{Mo} /\left(\mathrm{yoE}_{\mathrm{p}} \mathrm{I}_{\mathrm{p}}\right)$ は、等価地盤定数 $\beta_{\mathrm{a}}$ 、 $\beta$ 。るいは $\eta_{\mathrm{a}} 、 \eta_{\mathrm{o}}$ の1層地盤の式で計算できる。ここに、 $\omega$ は $\beta_{0}$ 、 $\eta_{0}$ を1層地盤の $\omega$ 式に適用して求め、 $\theta$ は1層地盤の $\theta-\omega$ 関係図 ${ }^{4)}$ から読みとればよい。

(5) $\mathrm{Mo} /\left(\mathrm{yoE}_{\mathrm{p}} \mathrm{I}_{\mathrm{p}}\right)$ の一定值に対する $\mathrm{M}_{\mathrm{m}} /\left(\mathrm{yoE}_{\mathrm{p}} \mathrm{I}_{\mathrm{p}}\right)$ は 1 層地盤に比べ、 $\mathrm{A}$ 夕 イプでは大きく、Bタイプでは小さい。これらの特性は、等価地盤 定数 $\beta_{0}$ と $\beta_{\mathrm{m}}$ あるいは $\eta_{\mathrm{o}}$ と $\eta_{\mathrm{m}}$ 值の相違として表現できる。

（6）任意の2層地盤において、skおよび Kgが変化する場合の杭基礎の $\mathrm{Mo} /\left(\mathrm{yoE}_{\mathrm{p}} \mathrm{I}_{\mathrm{p}}\right)-\mathrm{M}_{\mathrm{m}} /\left(\mathrm{yoE}_{\mathrm{p}} \mathrm{I}_{\mathrm{p}}\right)$ 関係は不規則な四辺形の領域を形成する。 この領域の上下限は、それぞれ上層あるいは下層の地盤定数をもっ た1層地盤の值であり、左右の限界は杭頭ピンおよび基礎固定の2層 地盤の值である。この図を利用して杭基礎の $\mathrm{M}_{\mathrm{m}} /\left(\mathrm{yoE}_{\mathrm{p}} \mathrm{I}_{\mathrm{p}}\right)$ 值を特定で きる。

(7) 2層地盤での $\mathrm{M}_{\mathrm{m}}$ の発生媣さ $\mathrm{L}_{\mathrm{m}}$ が層境界深さ $\ell_{1}$ と一致するのは、 特定のある深さの場合に限られる。この深さは、基礎固定の場合、 $\mathrm{A}$ タイプでは $\ell_{1}=\mathrm{L}_{\max }=1.74 / \beta$ あるいは $2.3 / \eta_{1} 、 \mathrm{~B}$ タイプでは $\ell_{1}=\mathrm{L}_{\min }=$ 1.4/ $\beta_{1}$ あるいは1.9/ $\eta_{1}$ である。Aタイプで $\ell_{1}<\mathrm{L}_{\text {max }}$ およびBタイプで $\ell_{1}<\mathrm{L}_{\text {min }}$ の場合、 $\mathrm{M}_{\mathrm{m}}$ は下層地盤内で発生する。その他の場合、 $\mathrm{M}_{\mathrm{m}}$

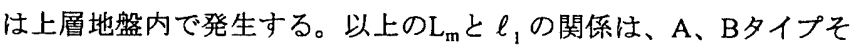
れぞれに折れ線で近似できる。基礎梁剛度一定の杭基礎の $\ell_{1}-\mathrm{L}_{\mathrm{m}}$ 関 倸は、基礎固定の折れ線に比例的な折れ線として特定できる。 (8) 以上の一般特性を利用することによって、架構をもった隅基礎、 中基礎についての妥当な応力・変形は簡単な計算で得られる。

\section{参考文献}

1)日本建築センター : 地震力に対する建築物の基礎の設計指針, pp.57-59, 1984.9

2)日本建築学会 : 鉄筋コンクリート構造設計指針・同解説, p.491, 1971.5

3)中澤瑤子，山肩邦男 : 架構剛性を考慮した群杭基礎の水平荷重時応力 略算法, 日本建築学会構造系論文報告集, 第404号, pp.129-134, 1989.10

4)中澤瑤子 : 杭と架構を一体とした弾性解析による杭基礎の応力変形系 (1層地盤の場合), 日本建築学会構造系論文報告集, 第512号, pp.127-132, 1998.10

5)横山幸満 : 〈い構造物の計算法と計算例，山海堂，1985 6)時松孝次, 中澤明夫, 大岡弘, 社本康広, 難波伸介 : 側方流動により 被害を受けた建物杭基礎の破壊・変形モード，土と基礎，Vol.45, No.3, pp.13-16, 1997.3,

7)中澤明夫, 蘓鉄盛史, 難波伸介, 中澤瑤子 : 兵庫県南部地震による建 物杭基礎の被害調查報告 (芦屋市の事例)：日本建筑学会技術報告集, 第3号, pp.77-85, 1996.12

8)武藤清 : 而震設計法シリーズ，丸善，pp.107-109，1963 9)B.B.Broms : Lateral Resistance of Piles in Cohesive Soils, Proc., ASCE, Vol.90, No.SM2, pp.27-63, 1964.3

（1998年12月 7 日原稿受理，1999年 4 月22日採用決定） 